\title{
Inversion tectonics: a brief petroleum industry perspective
}

\author{
Gábor Tari $^{1}$, Didier Arbouille ${ }^{2}$, Zsolt Schléder ${ }^{1}$, and Tamás Tóth ${ }^{3}$ \\ ${ }^{1}$ OMV Upstream, Exploration, 1020 Vienna, Austria \\ ${ }^{2}$ IHS Markit, Geneva, Switzerland \\ ${ }^{3}$ GeoMega Ltd, Budapest, Hungary
}

Correspondence: Gábor Tari (gabor.tari@ omv.com)

Received: 11 March 2020 - Discussion started: 30 March 2020

Revised: 5 August 2020 - Accepted: 24 August 2020 - Published: 21 October 2020

\begin{abstract}
Inverted structures provide traps for petroleum exploration, typically four-way structural closures. As to the degree of inversion, based on a large number of worldwide examples seen in various basins, the most preferred petroleum exploration targets are mild to moderate inversion structures, defined by the location of the null points. In these instances, the closures have a relatively small vertical amplitude but are simple in a map-view sense and well imaged on seismic reflection data. Also, the closures typically cluster above the extensional depocenters which tend to contain source rocks providing petroleum charge during and after the inversion. Cases for strong or total inversion are generally not that common and typically are not considered as ideal exploration prospects, mostly due to breaching and seismic imaging challenges associated with the trap(s) formed early on in the process of inversion. Also, migration may become tortuous due to the structural complexity or the source rock units may be uplifted above the hydrocarbon generation window, effectively terminating the charge once the inversion has occurred.

Cases of inversion tectonics can be grouped into two main modes. A structure develops in Mode I inversion if the synrift succession in the preexisting extensional basin unit is thicker than its post-rift cover including the pre- and syninversion part of it. In contrast, a structure evolves in Mode II inversion if the opposite syn- versus post-rift sequence thickness ratio can be observed. These two modes have different impacts on the petroleum system elements in any given inversion structure.

Mode I inversion tends to develop in failed intracontinental rifts and proximal passive margins, and Mode II structures are associated with back-arc basins and distal parts of passive margins.
\end{abstract}

For any particular structure the evidence for inversion is typically provided by subsurface data sets such as reflection seismic and well data. However, in many cases the deeper segments of the structure are either poorly imaged by the seismic data and/or have not been penetrated by exploration wells. In these cases the interpretation in terms of inversion has to rely on the regional understanding of the basin evolution with evidence for an early phase of crustal extension by normal faulting.

\section{Introduction}

While the concept of structural inversion has been around for a century (e.g., Lamplugh, 1919), the term was specifically used for the first time by Glennie and Boegner (1981) to explain the evolution of the Sole Pit structure located in the UK sector of the southern North Sea. At the same time, inversion structures called "Sunda-type folds" were described by Eubank and Makki (1981) in Indonesia. The first generalized description of structural inversion was offered by Bally (1984) using a three-step cartoon depicting an extensional half-graben subjected to subsequent contraction. Both the concept and the term of inversion tectonics gained rapid acceptance in the petroleum industry and academia as shown by the large number of papers produced on this subject in the 1980s and 1990s. In the two "classic" volumes on inversion tectonics by Cooper et al. (1989) and Buchanan and Buchanan (1995), numerous case studies were published using data sets provided by petroleum exploration companies (e.g., Roberts, 1989; Hayward and Graham, 1989; Badley et al., 1989; Cartwright, 1989). In addition, detailed outcrop studies combined with a good understanding of the structural 
geology context, done almost exclusively in fold and thrust belts (e.g., Butler, 1989; de Graciansky et al., 1989; McClay, 1989; Cooper et al., 1995; Flinch and Casas, 1996), offered an additional tool for recognizing inversion early on.

During the last 30 years many facets of inversion tectonics were addressed, including physical modeling (e.g., McClay, 1989, 1995; Buchanan and McClay, 1991; Mitra and Islam, 1994; Eisenstadt and Withjack, 1995; Keller and McClay, 1995; Yamada and McClay, 2004; Panien et al., 2005; Amilibia et al., 2005; Bonini et al., 2011; Granado et al., 2017; Roma et al., 2018; Ferrer et al., 2017), numerical modeling (e.g., Panien et al., 2006; Buiter et al., 2009; Granado and Ruh, 2019 ), basin modeling (e.g., Neumaier et al., 2016, 2017; Omodeo-Salé et al., 2019) and crustal-scale geodynamics (e.g., Ziegler, 1989; Ziegler et al., 1995; Cloetingh et al., 2008). Obviously, as 3D seismic reflection data became frequently used by the petroleum industry, more subsurface case studies addressed inversion tectonics quantitatively (e.g., Davies et al., 2004; Jackson and Larsen, 2008; Jackson et al., 2013; Reilly et al., 2017; Phillips et al., 2020).

There is a paper devoted to salt tectonics and inversion in this special issue (Dooley and Hudec, 2020), and, therefore, the very important role of salt tectonics in inversion tectonics will not be discussed in any details here, even though the cartoon by Bally (Fig. 1f) hints at the involvement of salt. Some of the key effects of salt during inversion include the decoupling of deformation above and below (e.g., Letouzey et al., 1995; Withjack and Callaway, 2000) and the sealing capacity of pre-, syn- and post-rift salt units impacting the hydrocarbon migration depending on the geodynamic setting of the salt basin (e.g., Rowan, 2014).

In this paper we provide a brief overview of inversion tectonics, specifically from the view point of the petroleum industry. The last 30 years have seen lots of work done on the practical application of this important structural geology concept in the hydrocarbon exploration process. While the impact of structural inversion has become increasingly evident in many case studies, in our opinion, there is room for improvement in two major aspects. Firstly, the term of structural inversion is being used in a very broad sense across the industry, which underlines the need to revisit the original definition of this process. There has to be a clear distinction between regional-scale and individual structure (prospect)specific inversion as these processes manifest themselves differently. Secondly, we observe an interesting disparity in the use of structural inversion in the petroleum industry. During the life cycle of many exploration and production projects, the interpretation of the trap(s) in terms of structural inversion is preferentially used during the exploration phase as it has, in general, a positive connotation for prospectivity (see below). In contrast, during the appraisal and production phase, the interpretation of the traps in a field in terms of inversion, as a trap-forming mechanism, typically becomes un(der)appreciated. We found that the description of existing fields generally lacks the reference to inversion tectonics as the trap-forming mechanism, but, instead, the trap itself is referred to as the result of reverse faulting or compression.

We provide below several case studies of regional-scale and prospect- or field-scale structural inversion to illustrate the typical challenges of applying this important concept in the petroleum industry. We chose drilled prospects and hydrocarbon fields from three very different basins to illustrate various aspects of the interpretational process of invoking inversion for the traps in these fields. The Budafa and Lovászi oil or gas fields in the Pannonian Basin of Hungary are onshore fields which were discovered in 1940 and are already depleted (Dank, 1985). There are numerous inversion structures in the Eastern Mediterranean; we show two of these located in the Egyptian offshore area: the Mango and the Goliath anticlines. Another inversion structure in the same region, the giant offshore Tamar gas field in the Israeli sector of the Levant Basin was discovered in 2009, and it started to produce just recently (Needham et al., 2017). The Atlantic margin of central Morocco also has lots of inverted structures due to the Cenozoic orogeny of the Atlas being superimposed on Mesozoic Tethyan rift systems.

While there are major differences between these inversion structures, they are similar in the sense that their inverted nature may not be always determined by analyzing them in isolation but only in a regional geologic context. Therefore, we will zoom out from the areas of these individual structures and will highlight the regional aspects of the inversion in the respective basins where they are located.

We intentionally chose examples where the inversion anticlines have an equal or thicker post-rift sequence than the underlying syn-rift basin fill. As a new observational model, we suggest that the inversion tectonics should be categorized into two main modes. The seemingly more common, but certainly more widely recognized, classic Mode I inversion is where the syn-rift succession, developed in the preexisting extensional basin unit, is thicker than its pre- and syn-inversion sequence part of the post-rift cover. In contrast, inversion anticlines developed in the so far underappreciated Mode II inversion have the opposite syn- versus post-rift succession ratio.

Finally, we offer a brief overview of the multifaceted impact of structural inversion on the petroleum systems as it is of paramount importance for hydrocarbon prospecting. In our experience, with regard to finding the optimum zone of inversion for hydrocarbon prospecting, the proper quantification of the inversion ratio tends to be a challenge. This may be due to a combination of factors such as (a) poor seismic imaging of the deeper section beneath an inversion anticline or (b) simply not having enough reflection seismic and/or well data available to determine all the geometric parameters necessary for calculating the inversion ratio. Therefore, a more practical approach is needed to quantify the inversion degree so it can be used in a predictive manner in petroleum exploration. 
INVERSION SEQUENCE

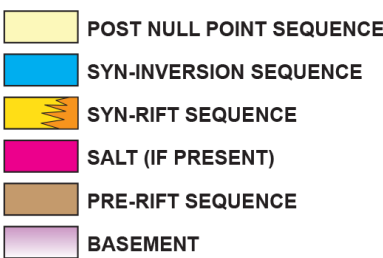

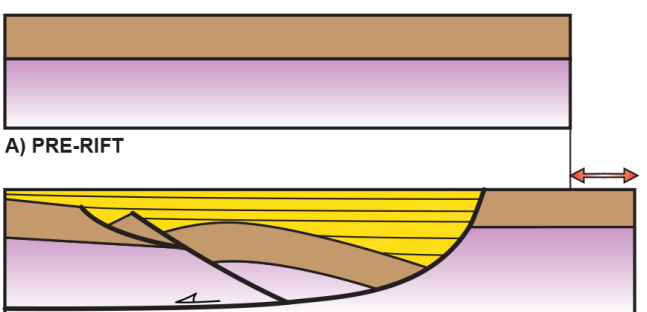

B) SYN-RIFT, NO GROWTH: I.E. SEDIMENTATION WAS UNABLE TO KEEP UP WITH EXTENSION

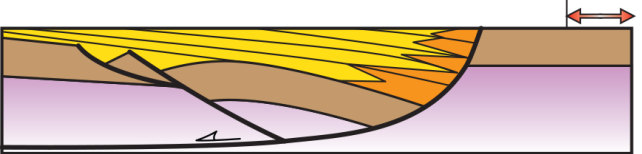

C) SYN-RIFT WITH GROWTH: UPDIP CONVERGENCE OF STRATA IN HANGING-WALL BLOCK, OPPOSITE CONVERGENCE ASSOCIATED WITH MINOR SUBSIDIARY HALFGRABEN

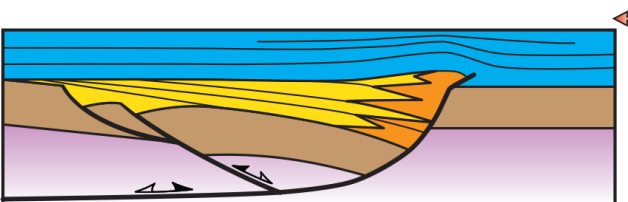

D) MINI-INVERSION: UPDIP CONVERGENCE OF SYNINVERSION STRATA OVER SMALL INVERSION ANTICLINE

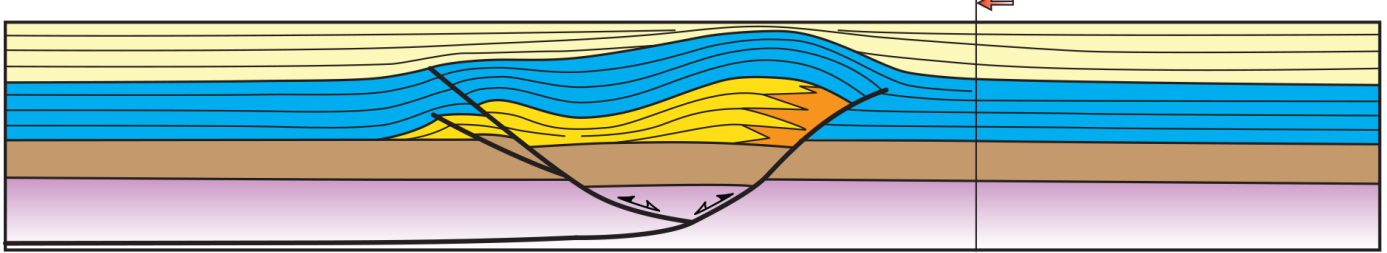

E) NEAR NULL POINT INVERSION: I.E. RESTORATION TO NEAR PRE-RIFT STATUS. UPDIP CONVERGENCE OF SYN-INVERSION SEQUENCE ON MAJOR INVERSION ANTICLINE AND MINOR SUBSIDIARY INVERSION ANTICLINE

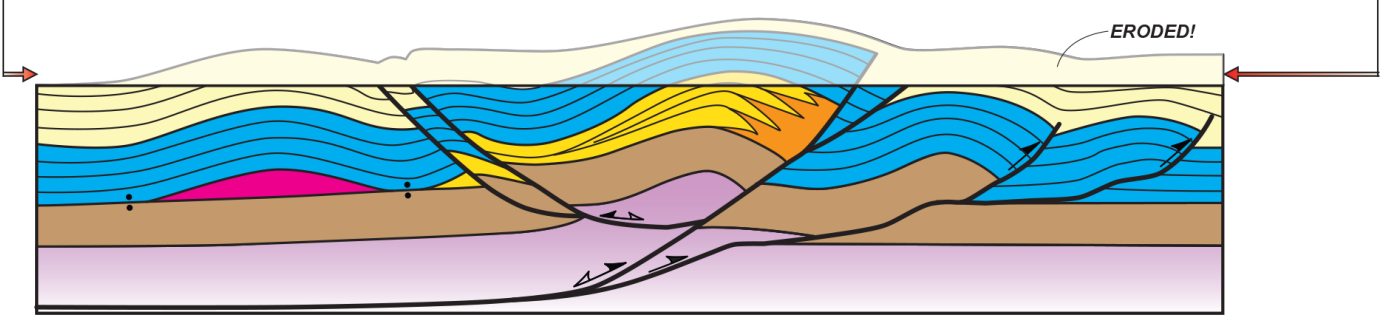

F) POST NULL POINT CONTRACTION: FORMATION OF BASEMENT-INVOLVED REVERSE FAULTS, SATELLITE DECOLLEMENT FOLDED BELTS AND COMPRESSIONAL SALT ANTICLINES

Figure 1. Extended version of Bally's (1984) original inversion model. This cartoon was redrafted after an unpublished figure made by Albert W. Bally in the early 2000s at Rice University to show the progression of inversion tectonics into the formation of an incipient folded belt. Specifically, he made this cartoon with the western High Atlas of Morocco in mind (e.g., Hafid et al., 2006); that is why salt is shown here as a detachment level accommodating some of the contraction.

\section{An unpublished cartoon on inversion tectonics by Albert W. Bally}

The first generalized description of structural inversion was offered by Bally (1984) using a cartoon depicting the evolution of an extensional half-graben subjected to subsequent contraction in three steps. Interestingly, we have found an unpublished extended version of Bally's original inversion model which he designed during the early 2000s at Rice University to show the progression of inversion into the formation of an incipient folded belt (Fig. 1). Specifically, he made this cartoon to illustrate the development of the western Atlas in Morocco. While the inversion at the western termination of the Atlas system has already been described by Hafid et al. (2006), we felt that it is proper to reproduce in this special issue of Solid Earth Bally's own schematic summary of inversion tectonics which was left out from that paper (Fig. 1). Importantly, in this unpublished version he added some new elements to his original visual summary (Bally, 1984). In the description of the cartoon summary below we also use some of his unpublished text. 
The term inversion tectonics should in our view be restricted to situations where extensional and/or transtensional systems are inverted to form inversion anticlines. Figure 1 attempts to sum up the main characteristics of these systems. During the extensional phase, stratal geometries vary between two end-members depending on the relative rates of sedimentation versus horizontal extension (Fig. 1b and c). Rates of sedimentation which keep up with the extension lead to the familiar growth pattern in the half-graben with characteristic updip convergent strata. In contrast, when sedimentation rates lag behind the extension rates, it will result in the subhorizontal infill of the half-grabens.

Minor (or mini) inversions involve partial inversion of the graben fill (Fig. 1d), which could be difficult to differentiate from forced folds (e.g., Withjack et al., 1990) associated with extensional tectonics.

These structures can be distinguished using a simple criterion - i.e., forced folds are monoclines, with one side below "regional" (regional in this context refers to the regional elevation, which is the structural elevation of a marker horizon at its undeformed level, e.g., Cooper and Warren, 2010), whereas inversion structures are anticlines that are above regional (Mark Rowan, personal communication, 2020).

The inversion can proceed until the extensional system is restored to its pre-kinematic configuration, reaching the null point (Fig. 1e) sensu Williams et al. (1989). As inversion advances further, essentially coplanar reverse faults and/or short-cut faults may form (Fig. 1f). Minor subsidiary décollement systems will eventually appear on the flanks of the uplifts as the stresses are transmitted along the competent strata of the foreland adjacent to both sides of the inversion system.

On seismic reflection profiles inversion structures are characterized by thick asymmetrical anticlinal cores representing the extensional regime with a short, steeper forelimb and a longer, gentler, more planar back limb. The overlying strata thinning onto the structure on both flanks represent the inversion regime. The later updip convergence sequence is most prominent over the maximum graben fill (Fig. 1e) and thus differs from the updip convergence associated with the earlier extensional phase (Fig. 1b). The inversion sequence provides timing constraints for the inversion phase but because of its high position on the structure, it is frequently eroded (Fig. 1f).

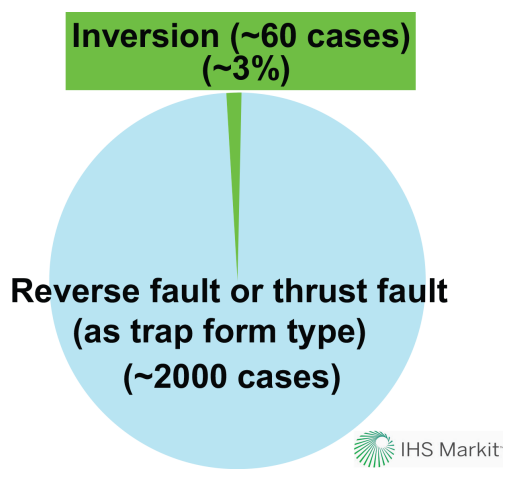

Figure 2. Outcome of a worldwide (excluding onshore US and Canada) database search using hydrocarbon fields and discoveries with circa 2000 reservoir units. In these reservoir units the "trap form" type was classified as reverse fault or thrust fault. Interestingly, within these 2000 cases we have found only about 60 matches for inversion as a trap-forming mechanism. This translates into only about $3 \%$, a strikingly low proportion. We believe that inversion tectonics may be unrecognized in many fields globally, and therefore it remains underreported. Courtesy of IHS Markit.

\section{A worldwide database on petroleum fields: reported cases of inversion tectonics}

To determine to what degree structural inversion is understood and recognized in the process of exploration, development and production of hydrocarbons, we decided to conduct a data mining exercise. In petroleum industry practice, the traps of producing reservoir units in hydrocarbon fields are always specifically described as this provides critical information.

We had access to a very large, almost worldwide (excluding onshore US and Canada), comprehensive database on hydrocarbon fields and discoveries (IHS Markit, 2020). This database differentiates between the "trap form type" described in any given field (like "reverse fault" or "thrust") and the "trap-forming mechanism" (like "compression" or "inversion"). Obviously, the trap form type is a simpler, observational category compared to the trap-forming mechanism, which is a more complex, interpretational category.

A query for the word "inversion" under the trap-forming mechanism in this huge worldwide database (IHS Markit, 2020), containing detailed information on about 31000 fields and discoveries with about 70000 reservoir units, provided 720 field and about 2000 reservoir unit matches. Interestingly, this means that only about $2.3 \%$ of the fields were classified as inversion under the trap-forming mechanism. On the level of individual reservoir units within all the hydrocarbon fields worldwide, the corresponding number is $1.7 \%$.

Another database query on circa 2000 reservoirs worldwide (excluding onshore US and Canada) classified as reverse fault or "thrust fault" in the trap form type provided only about 60 matches for inversion as a trap-forming mechanism. This translates into about $3 \%$ - again, a very low pro- 
portion of the reported cases (Fig. 2). We believe that these low percentages for reported inversion tectonics in hydrocarbon fields and their reservoir units might be related to the fact that detailed trap descriptions are always difficult to obtain from the operators of these fields. Moreover, the relevant information for the correct classification and reporting is rarely available in publications.

Therefore we believe that during the life cycle of many exploration, appraisal, development and production projects, the term inversion is often used quite loosely during the initial exploration and appraisal phase. In contrast, during the development and production phase the exact meaning of inversion as a trap-forming mechanism becomes irrelevant many times, and it is replaced in the reporting practice by the more generic compression or "overthrusting" descriptors. In other words, whereas inversion tectonics appears to be somewhat overstated in exploration, it is quite possibly underreported in production projects.

Another important consideration is the fact that structural inversion has become well known only since the 1980s. Therefore, the traps of many hydrocarbon fields discovered before had already been classified as the result of simple compression or overthrusting. One of the examples we discuss below, a large onshore oil and gas field discovered in Hungary in 1940, clearly illustrates this situation. The trap of the Lovászi field has been traditionally described as a compressional anticline in keeping with the structural observations made long before the advent of inversion tectonics.

\section{Case studies from the Pannonian Basin, Hungary: the Budafa and Lovászi oil and gas fields}

In the basin classification scheme of Bally and Snelson (1980), the Pannonian Basin is the prototype for back-arc basins where extension did not advance to the opening of an oceanic basin. Large but subtle surface anticlines had been known in the western Pannonian Basin for a long time (Fig. 3) and were referred to as the "Sava Folds" after a local river in the border zone between Slovenia, Croatia and Hungary (Stille, 1924). Based on the regional compilation of vertically exaggerated composite seismic lines in this area, Tari (1994) found many cases of very young, in many cases ongoing, uplift of the pre-Cenozoic basement from below the Neogene basin fill. This upwarping occurs at different wavelengths (Fig. 4), and it is still ongoing (Ruszkiczay-Rüdiger et al., 2005, 2020). The small features include local folding and/or thrusting of the post-tectonic cover with the inversion of syn-rift structures. While these Sava Folds have mapview dimensions on the scale of tens of kilometers, there are much larger-scale neotectonic uplifts in the Pannonian Basin (Fig. 4). In particular, the Transdanubian Range of western Hungary experienced significant neotectonic uplift and exhumation during the Quaternary, with a wavelength of about $100 \mathrm{~km}$. Tari (1994) distinguished between these two end- member categories of uplift with different wavelengths and, for the first time, attributed them to regional-scale and localscale inversion tectonics. In particular, the map view of the smaller-scale inverted structures (Fig. 3) suggests that the inversion and uplift are propagating into the intra-Carpathian region from the west (Tari, 1994). Indeed, in situ stress measurements showed compressive stresses in the western part of the Pannonian Basin, while tensile stresses were obtained in the eastern part (e.g., Dövényi and Horváth, 1990). On the scale of the entire Pannonian Basin, the inverted structures concentrated at the western margin of the basin have gradually been propagating eastwards into the basin since the late Pliocene. Both the regional-scale and local-scale inversions are driven by the ongoing shortening in the broader area, including the Alps, between the Adriatic promontory of Africa and the European plate (Tari, 1994; Horváth, 1995; Horváth and Tari, 1999; Bada et al., 1999, 2007; Tomljenovic and Csontos, 2001; Vrabec and Fodor, 2006; Horváth et al., 2006). Indeed, borehole breakout data indicate a NS-oriented $\sigma 1$ with $\sigma 3$ also being horizontal corresponding to a transpressional strike-slip regime (Tóth and Tari, 2014). While the local-scale inversions are attributed to the reactivation of preexisting extensional normal faults in an intra-plate compressive stress field, the basin-scale inversions (Fig. 3) are due to large-scale positive deflection of the lithosphere reacting to the buildup of the same stress field (Horváth and Cloetingh, 1996; Cloetingh et al., 2006). As another contributing factor to neotectonic inversion, Bada et al. (2001) analyzed the role of topography-induced gravitational stress in basin inversion in the Pannonian Basin. They found that the kinematics of the inversion of the western Pannonian Basin is consistent with topography-induced gravitational stress which locally exceeds the magnitude of the far-field stress (Bada et al., 2001).

\subsection{The Budafa field}

The Sava Folds offered obvious drilling targets for hydrocarbon exploration in the first half of the 1900s (e.g., Dank, 1985). The breakthrough came in 1937 when the Budafa anticline was drilled (Fig. 5) as it was the first significant discovery during the hydrocarbon prospecting efforts in post-World War 1 Hungary (e.g., Tari and Berczi, 2018). The upper Pliocene (Pannonian) beds outcrop at the surface with dips between 3 and $10^{\circ}$ defining an anticlinal four-way closure of about $18-20 \mathrm{~km}^{2}$. Subsequent appraisal and development drilling established multiple oil and gas reservoir units within the lower Pannonian part of an east-west-striking folded anticline at 900 to $1300 \mathrm{~m}$ depth. The $2 \mathrm{D}$ vintage reflection seismic illustration of the Budafa field (Fig. 5) is oriented perpendicular to the fold axis. It shows the asymmetric nature of the anticline suggesting an underlying master fault on the northern flank of the structure. Even on this moderate-quality vintage line acquired in the early 1980s one can interpret the thickening of the upper-middle Miocene ("Sarmatian- 


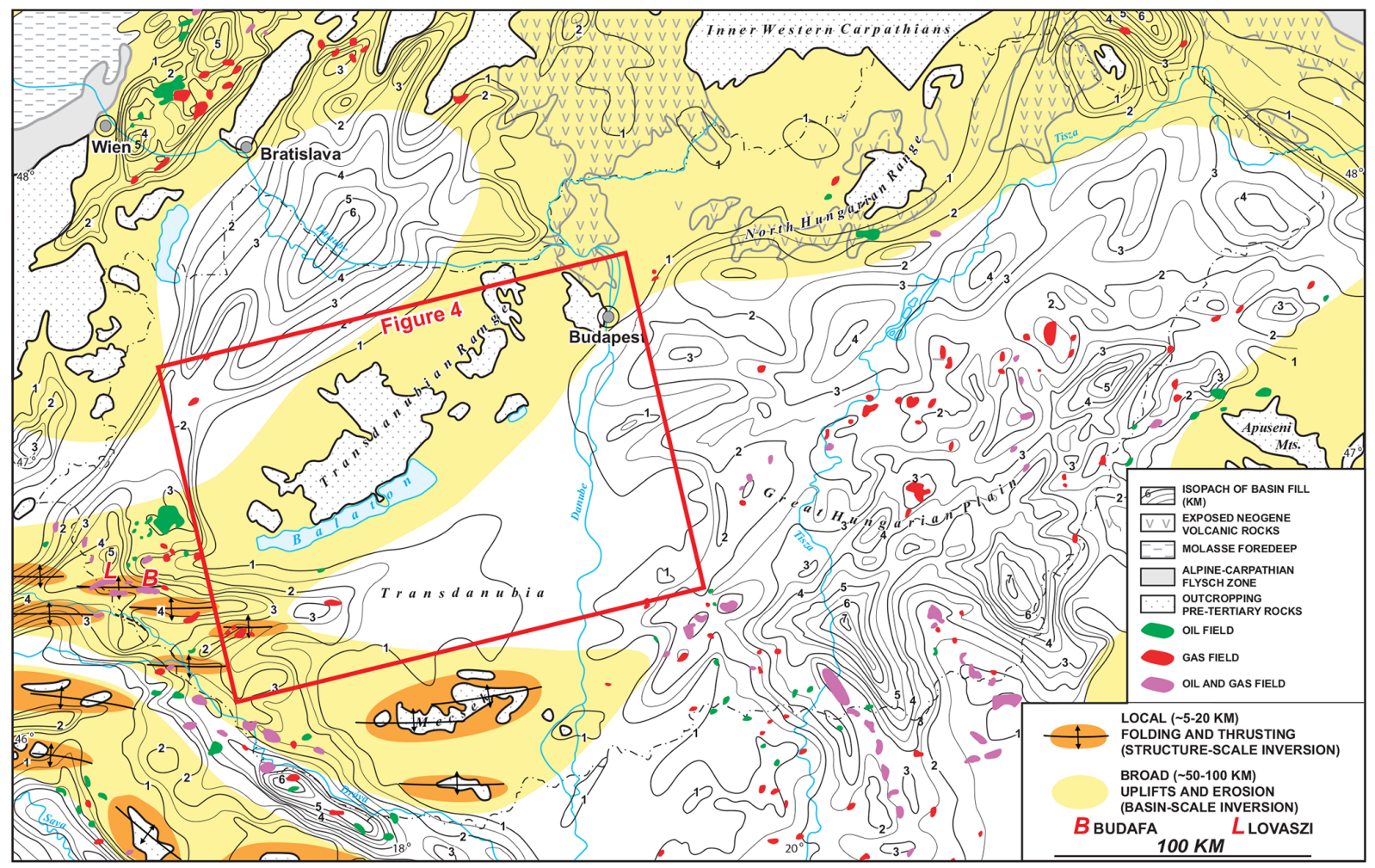

Figure 3. Regional map of the central part of the Pannonian Basin adapted from Tari (1994), who distinguished for the first time between two classes of inversion tectonics in this basin. These two end-member categories of uplift are attributed to regional-scale and local-scale structural inversion tectonics. The map-view pattern of the smaller-scale inverted structures suggests that inversion and uplift are propagating into Pannonian Basin from the SW driven by the Adria plate. The isopach of the basin fill and the location of hydrocarbon fields are based on Tari and Horvath (2006).

Tortonian-Helvetian") strata beneath the apex of the anticline providing evidence for the latest Pliocene to Quaternary inversion of a Miocene syn-rift graben. However, the seismic data quality is not good enough to properly delineate the position of the master fault, let alone that of the null point.

\subsection{The Lovászi field}

We chose another example of the Sava Folds which provided an important oil and gas find in the region. One of the first major oil fields discovered in Hungary, Lovászi, is also an inversion anticline delineated by potential field data and surface dip measurements in the western Pannonian Basin in 1940. As this particular exploration play was relatively simple, i.e., E-W-trending anticlines with relatively shallow Pliocene to Miocene clastic reservoir targets, all the prospects of this play were drilled up as early as the 1940s (Dank, 1985) and most of them are essentially depleted by now.

Based on abundant well control, the Pliocene to Miocene succession in the broader area was studied by Juhász (1994, 1998). Her subregional lithostratigraphic transect, crossing the Lovászi field (Fig. 6), clearly shows a prominent surface anticline with a vertical relief of about $800-1000 \mathrm{~m}$ in the
Pliocene to upper Miocene (Pannonian; Sarmatian to Badenian) strata compared to their regional levels in this part of the Pannonian Basin. The Lovászi anticline is depicted as a slightly asymmetric one, therefore, in our interpretation, suggesting an underlying master syn-rift fault on its southern flank (Fig. 6). However, given the lack of deep wells penetrating the entire syn-rift core of the inversion anticline, the geometry of the inferred master fault and the location of a null point along it cannot be established using well data only.

As there are modern $3 \mathrm{D}$ seismic data available covering the entire Lovászi field (Tóth and Tari, 2014), the structural history of this anticline can be studied in the context of its inverted nature (Fig. 7). The interpretation of the seismic data (Fig. 7a) reveals the growth of an anticline in the manner depicted in Bally's cartoon (Fig. 1). In particular, the thickening-thinning geometries within the Miocene (Badenian) to upper Pliocene (Pannonian) strata in the apex of the anticline show the switch from extension to compression (Fig. 7a). Interestingly, flattening on multiple seismic horizons demonstrated an early growth episode of the anticline during the early Pannonian already focusing hydrocarbon migration into the structure (Tóth and Tari, 2014). The main period for the formation of the anticline, however, is 


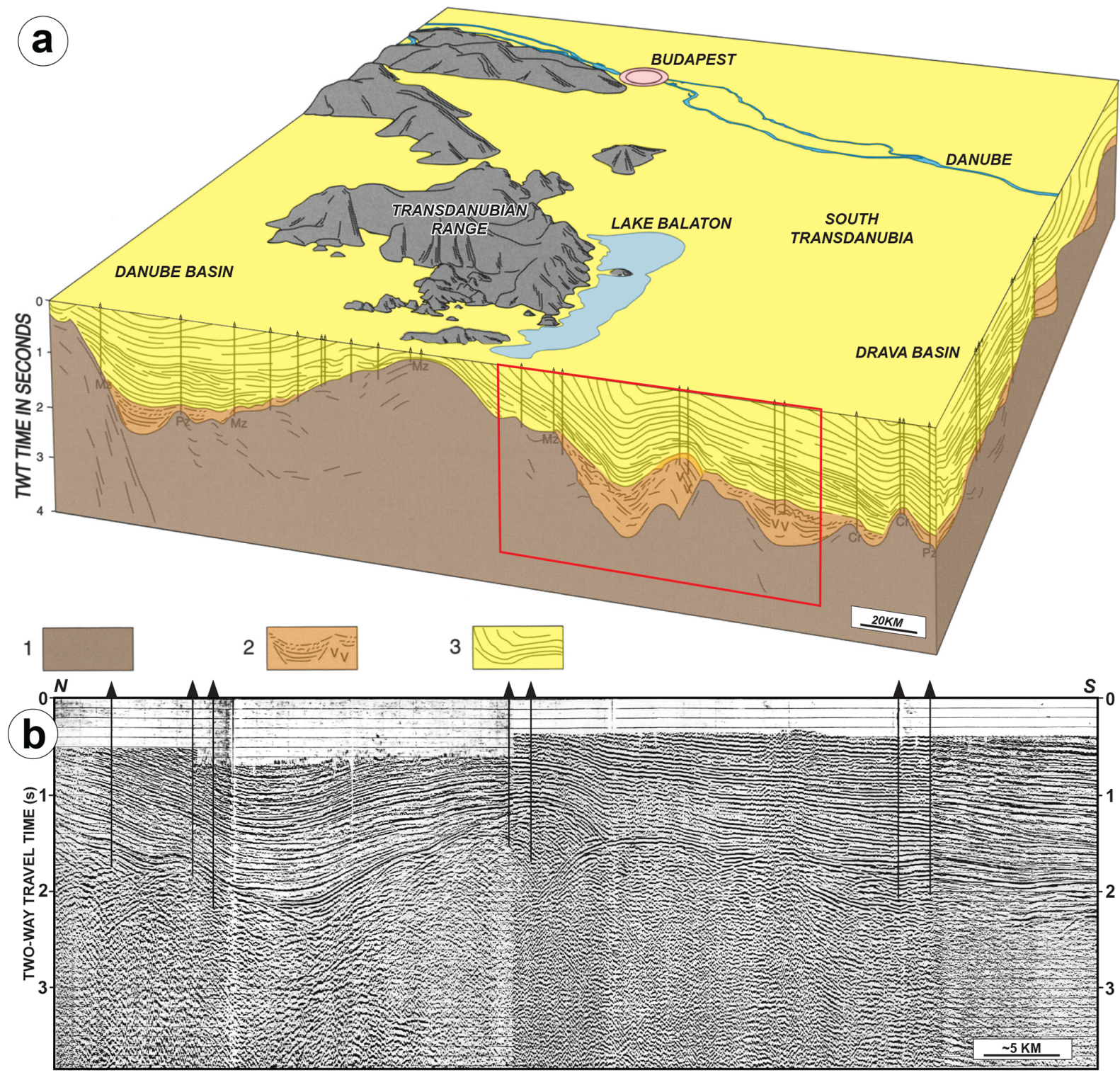

Figure 4. (a) Block diagram of the Transdanubian part of the Pannonian Basin to illustrate the structural and stratigraphic conditions and their relation to surface morphology. The regional-scale upwarping of pre-Cenozoic rocks of the Transdanubian Range north of Lake Balaton (for location, see Fig. 3) is the consequence of Pliocene to Holocene basin inversion (adapted from Horvath and Tari, 1999). Legend: 1, Mesozoic-Paleozoic bedrock; 2, mid-Miocene syn-rift strata; 3, late Miocene to Pliocene post-rift strata. (b) Composite vintage 2D seismic section (Tari, 1994; Rumpler and Horváth, 1988) as part of the regional seismic line shown above as a line drawing. The core of the young anticline in the center was drilled by wells Vése- 1 and -2 and penetrated thick syn-rift Miocene strata. The overall geometry of the structure suggests that a syn-rift half-graben was inverted, just like in the case of the Budafa anticline (Fig. 5).

clearly post-Pannonian as all the Pannonian reservoirs levels are gently folded (Fig. 7c) into low-amplitude four-way closures (Fig. 7b).

Historical production from the multiple Pannonian reservoirs of the Lovászi field (Fig. 7c) was about $50 \mathrm{~mm}$ bbl oil (bbl refers to barrels) and $230 \mathrm{bcf}$ gas (bcf refers to billion cubic feet). Current exploration efforts are focusing on the deeper parts of these anticlines where reservoir quality prediction and imaging of viable traps are the main challenges
(Tóth and Tari, 2014). As most of these anticlines are the products of Pannonian (Pliocene) to Quaternary inversion of middle Miocene syn-rift half-grabens, a proper structural understanding of the core of the anticlines is critical for any future exploration efforts. 


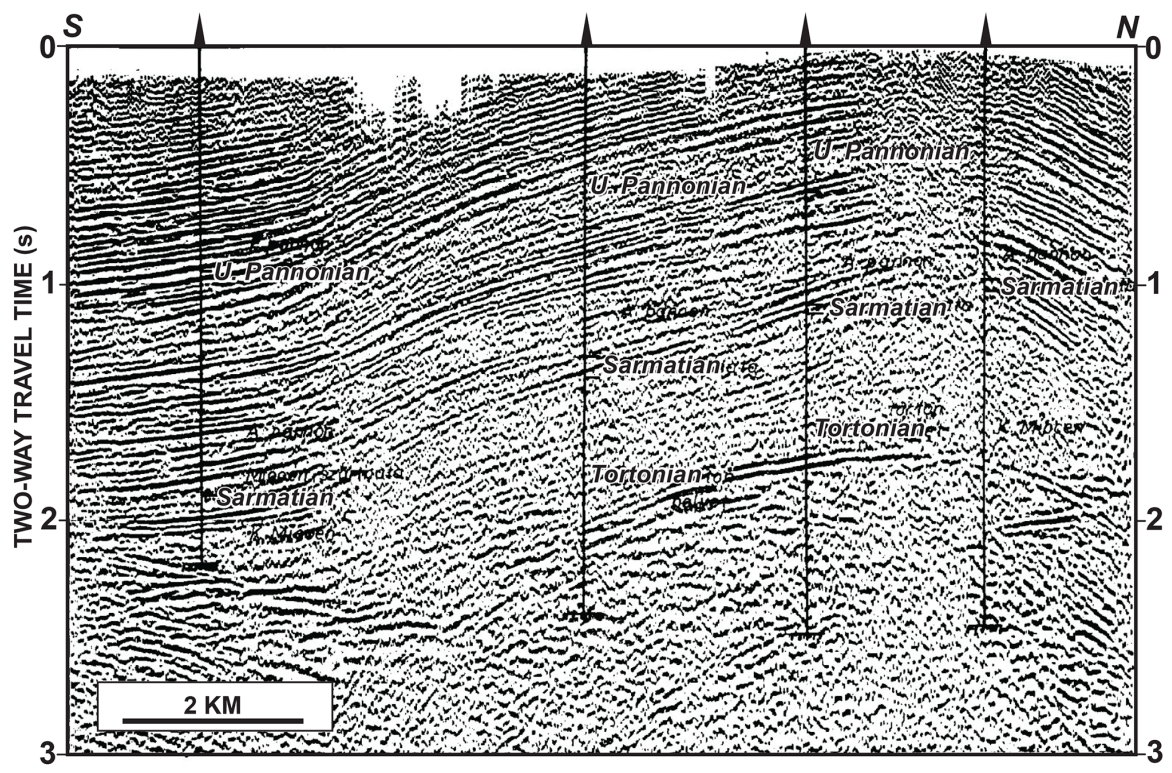

Figure 5. Vintage 2D reflection seismic illustration of the Budafa field (Dank, 1988; Pogácsás et al., 1994). The asymmetric nature of the surface anticline suggests an underlying master fault on the northern flank of the structure. Even on this moderate- to poor-quality vintage line one can interpret the thickening of the upper-middle Miocene ("Pannonian-Sarmatian-Tortonian") strata beneath the apex of the anticline. This provides evidence for the latest Pliocene to Quaternary inversion of a preexisting Miocene syn-rift half-graben. Unfortunately, the seismic data quality is not good enough to properly delineate the position of the master fault, let alone that of the null point.

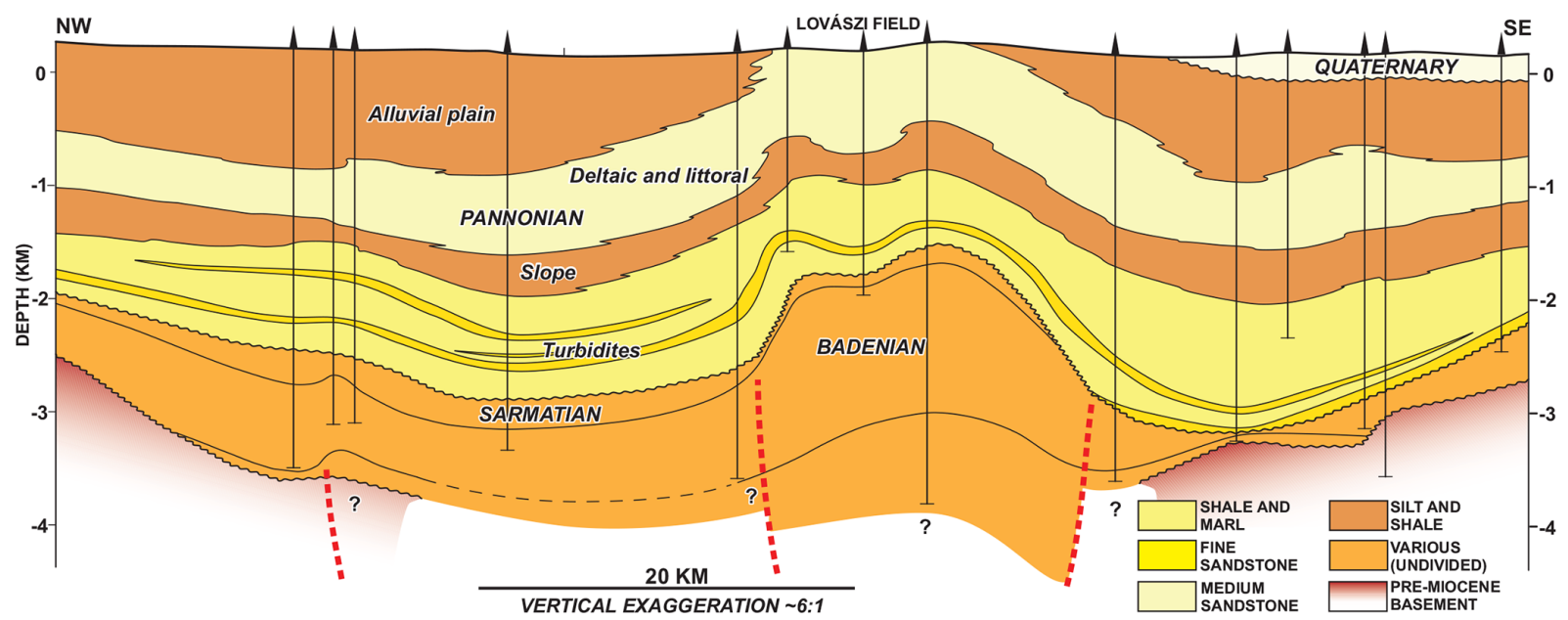

Figure 6. This subregional lithostratigraphic transect, crossing the Lovászi field, was redrafted after Juhász (1994, 1998). Her study was not devoted to the structural evolution of the area but rather to the correlation of various lithologies of the Miocene and Pliocene sequence primarily using well data. Note the missing Pannonian sequence above the Lovászi anticline, which could have an 800-1000 m thickness. Given the slightly asymmetric shape of the Lovászi anticline, we inferred the presence of a master syn-rift fault and added it to the original illustration (dashed red line) beneath its southern flank (cf. Fig. 7).

\section{Case studies from the Eastern Mediterranean: the Mango and Goliath structures and the Tamar gas field}

The Eastern Mediterranean is another region where numerous inversion anticlines have been described for about a century (Fig. 8). These Syrian Arc structures, as named by
Krenkel (1925), extend from the Sinai to the Palmyrides with a typical trend of ENE-WSW to NNE-SSW (e.g., Walley, 1998). These prominent features formed by the inversion of preexisting Mesozoic extensional structures from Late Cretaceous to Oligocene times. Two main phases of folding have been documented. The first one can be dated as intra- 


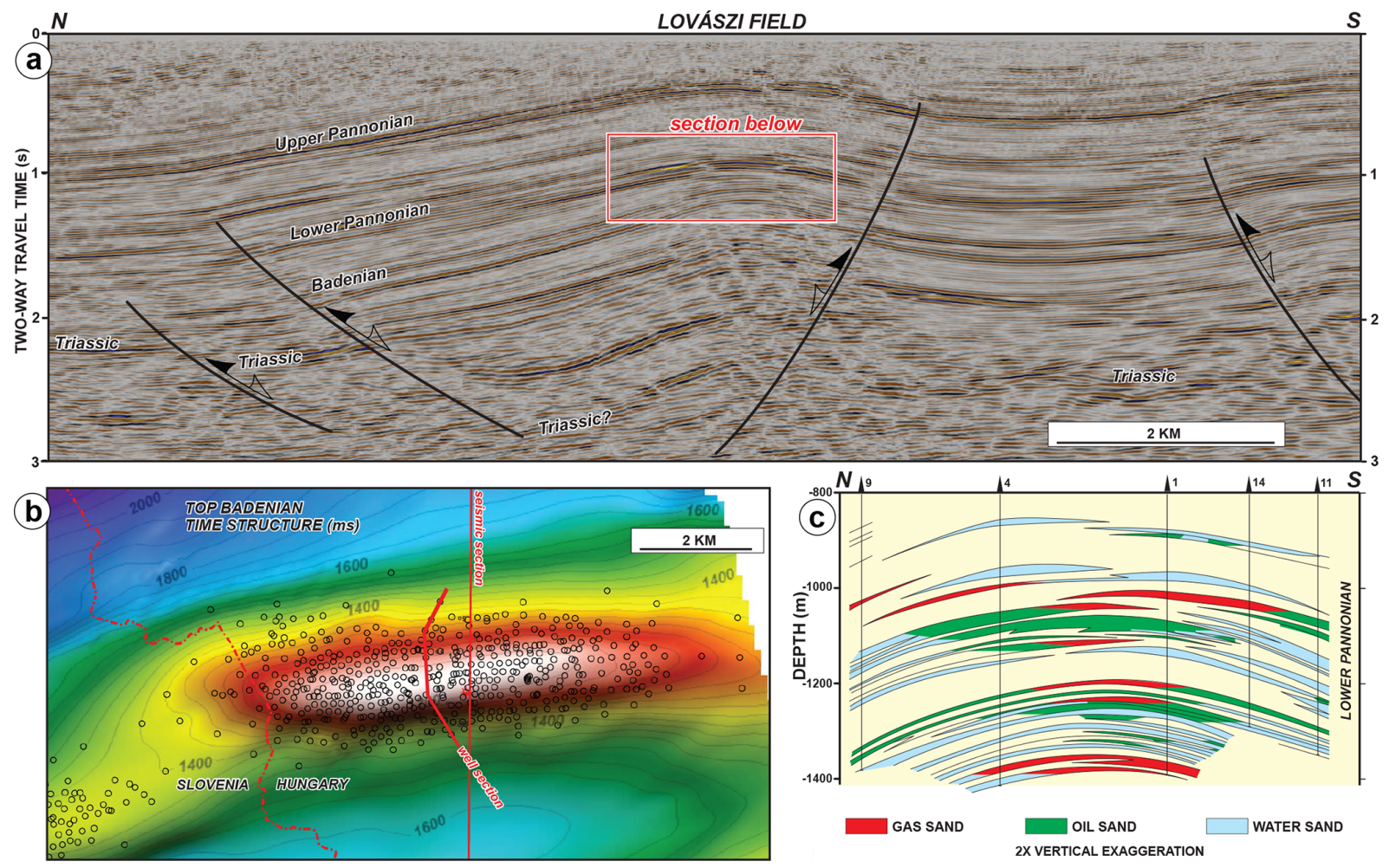

Figure 7. Highlights of the Lovászi field, at the border of Hungary and Slovenia; for location, see Fig. 3. (a) Three-dimensional reflection seismic example across the field adapted from Tóth and Tari (2015) with no vertical exaggeration assuming a $3 \mathrm{~km} \mathrm{~s}^{-1}$ average seismic velocity. (b) Two-way travel time structural map on the top Badenian (middle Miocene) seismic horizon with a $25 \mathrm{~ms}$ contour interval. (c) Well-based cross section across the central part of the field redrawn from Dank (1985).

Santonian (early Syrian Arc phase), and the second is dominantly a late Eocene series of events (late Syrian Arc phase).

From an exploration point of view, the Syrian Arc structures are very important. For example, the traps within several onshore Egyptian hydrocarbon fields are formed by Syrian Arc events (e.g., Dolson, 2003). Also, middle to late Cenozoic Syrian Arc-style compressional features are present in the deepwater of the Eastern Mediterranean, providing the traps for many deepwater discoveries during the last decade (Gardosh et al., 2008; Gardosh and Tannenbaum, 2014).

It is important to emphasize, that not all Syrian Arc anticlines are basement-involved structures and, therefore, not all of them are inverted features in the strict sense of the word (e.g., Cooper et al., 1989). A regional Upper Triassic salt sequence provided an effective detachment surface for numerous anticlines in the Damascene segment of the Arc in Syria (Wood, 2015). However, the involvement of the basement in the Palmyrides cannot be excluded for every anticline, so there may be a case for decoupled inversion due to the influence of salt.

In northern Egypt (Fig. 8), sedimentation during the Late Cretaceous was interrupted during the Santonian by the development of inversion-related folds (Moustafa, 1988;
Guiraud and Bosworth, 1997; Bosworth et al., 1999, 2008). The Egyptian segment of the Syrian Arc extends from the Western Desert to the northern Sinai. The Syrian Arc inversion anticlines have been described from the subsurface and using outcrop studies in the Western Desert (Moustafa et al., 1998, 2003; Yousef et al., 2019), west of Cairo (Moustafa, 1988), in the Eastern Desert (Moustafa and Khalil, 1995) and in the northern Sinai (Moustafa and Khalil, 1995; Yousef et al., 2010). The formation of the Syrian Arc has been attributed by Guiraud and Bosworth (1997) to changes in the Africa-Arabia plate motion with respect to the Eurasian plate at the end of the Santonian.

In Israel and Palestine, mostly subsurface data suggest that many of the Syrian Arc structures are in fact associated with the reverse reactivation of preexisting Triassic and Jurassic extensional faults (Freund et al., 1975; Druckman et al., 1995). Contraction started in the latest Cretaceous and continued through the Neogene (Eyal and Reches, 1983; Eyal, 1996; Walley, 1998). Just like on the regional scale, two periods of inversion tectonics were documented using reflection seismic and well data. An earlier phase of Senonian to Eocene inversion was followed by a later phase in the Miocene (Gardosh and Druckman, 2006). Interestingly, early Syrian Arc phase (Syrian Arc I) inverted struc- 


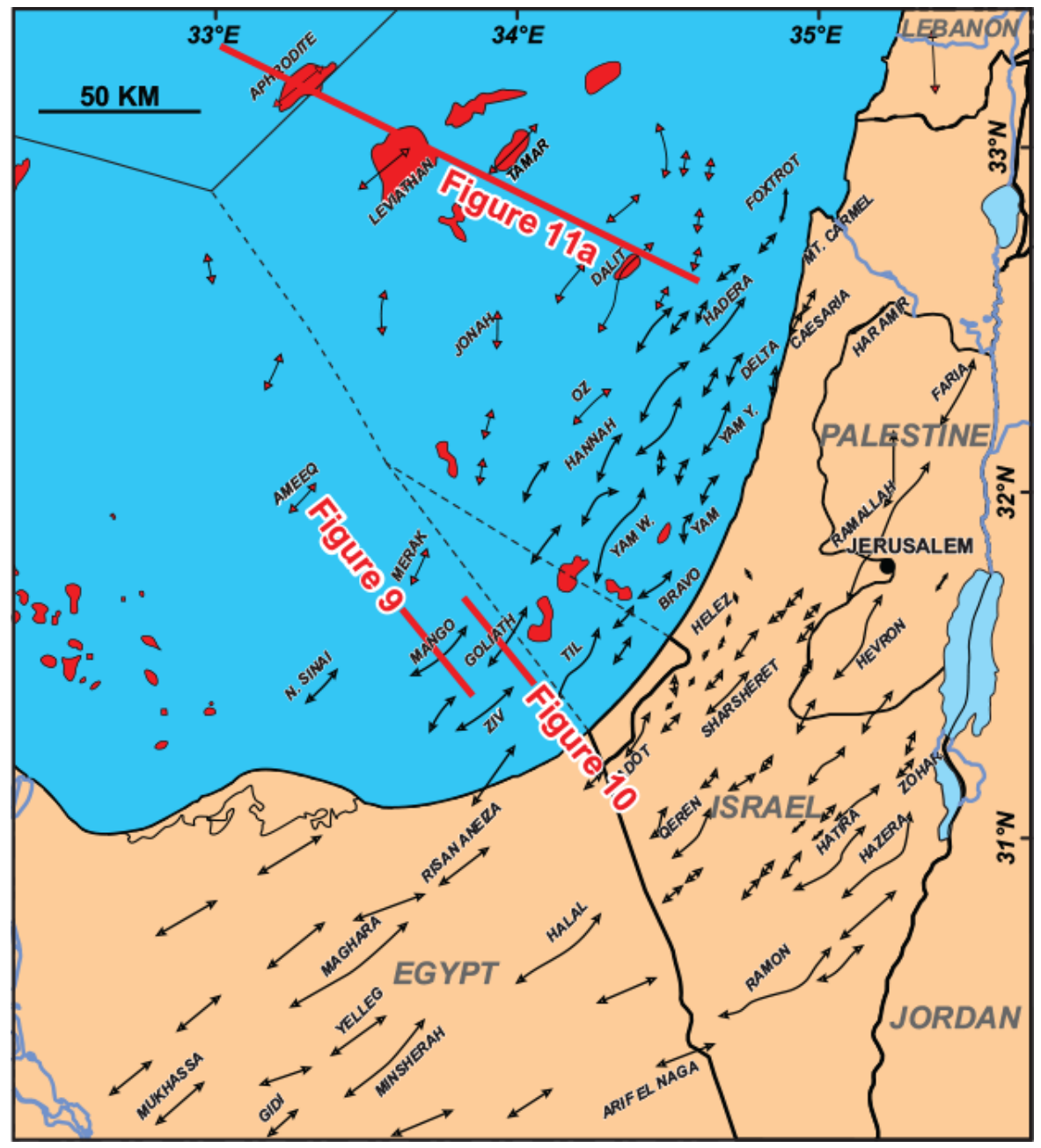

Figure 8. Inventory of the Syrian Arc anticlines, in the border region between Egypt and Israel, modified from Gardosh and Tannenbaum (2014) with some additions in the Egyptian offshore area. The anticlinal axes in black correspond to the early Syrian Arc deformation (Late Cretaceous to Paleogene), whereas the red ones formed during the late Syrian Arc inversion (late Cenozoic). Note the location of the Mango, Goliath and Tamar anticlines in Egypt and Israel (Figs. 9, 10 and 11).

tures are mostly located onshore and in the narrow shelf area of the Levantine Basin (Fig. 8). Most of these thrust-faultcontrolled structures are asymmetric anticlines with high amplitude and short wavelength (Gardosh and Tannenbaum, 2014). In contrast, the inversion anticlines of the late Syrian Arc phase (Syrian Arc II) are found in the offshore part the Levantine Basin (Fig. 8). These structures are subtle, generally having a low amplitude but large map-view closure (Gardosh and Tannenbaum, 2014). They also appear as just subtly asymmetric folds which were still active during the Messinian (see below). Their inversional origin may not be obvious given the fact that the underlying Paleozoic(?)Mesozoic extensional structural fabric is typically poorly imaged in the deepwater Levant Basin due to the great depth. However, the better-imaged inboard Syrian Arc I anticlines (Fig. 8) provide very good structural analogues (Gardosh et al., 2008).

\subsection{Inverted "Syrian Arc I" structures offshore Egypt: the Mango and Goliath structures}

As subsurface examples of a typical Syrian Arc inversion anticline, we chose two offshore Sinai structures in Egypt (Fig. 8). The Mango structure (Fig. 9) is a circa $24 \mathrm{~km}$ long, WSW-ENE-oriented anticline (Yousef et al., 2010). After an initial oil discovery drilled on the structure in 1986, two more appraisal wells have been drilled to test the potential of the Lower Cretaceous clastic sequence in this inverted structure. The thickening-thinning relationships within the Mesozoic-Cenozoic sequence define a Jurassic to Early Cretaceous period of normal faulting along a poorly imaged master fault (Fig. 9). In contrast, the overlying, mostly Cenozoic sequence displays progressive onlap onto the apex of the anticline. 


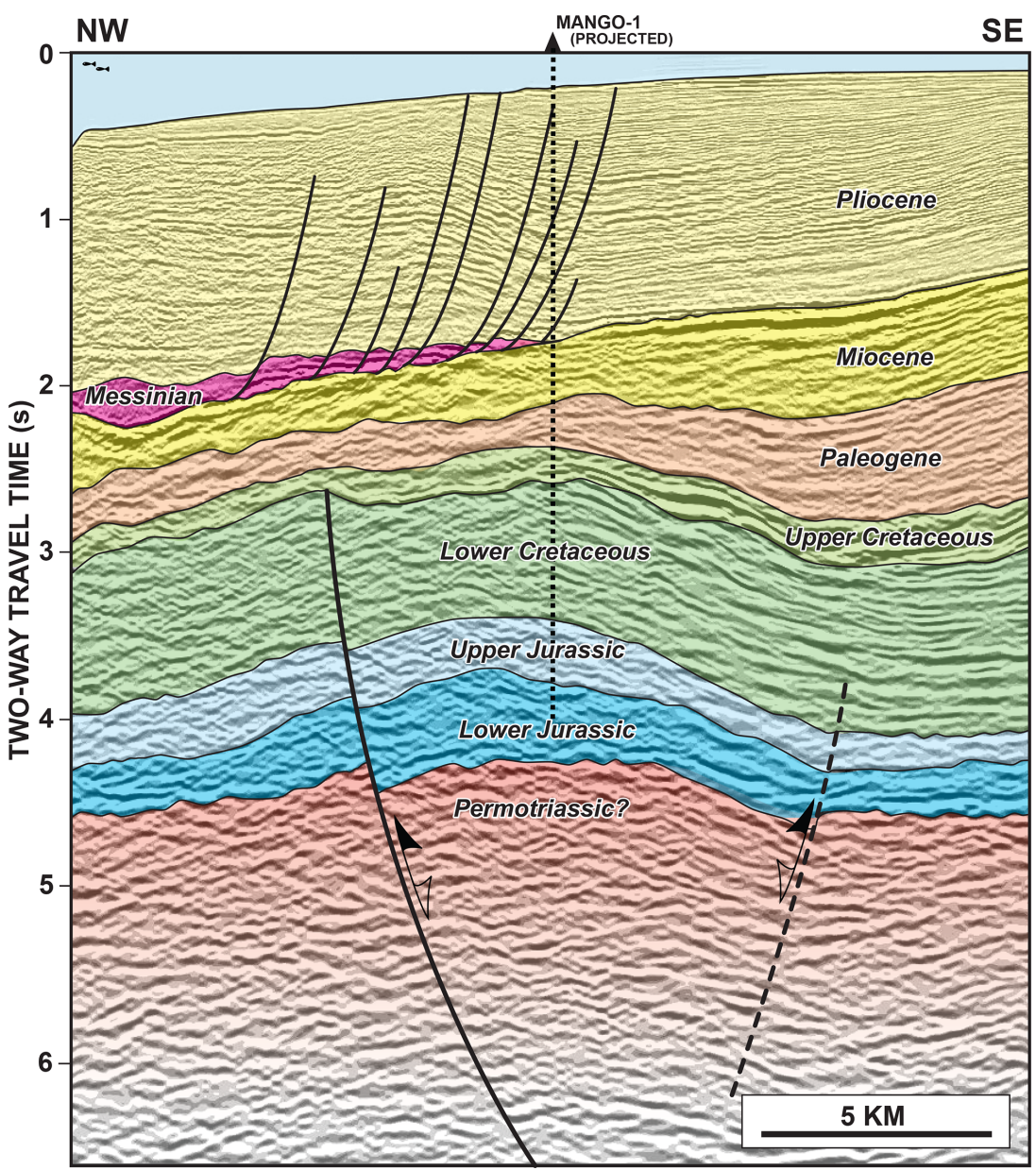

Figure 9. Two-dimensional reflection seismic profile across the Mango oil discovery offshore Sinai, Egypt (see location in Fig. 8). The synrift master fault controlled the deposition of the Lower Jurassic to Lower Cretaceous sequence. The subsequent Late Cretaceous to Paleogene Syrian Arc inversion period is responsible for the formation of the asymmetrical anticline (modified after Yousef et al., 2010).

The Goliath structure (Fig. 10) is a circa $20 \mathrm{~km}$ long, SWNE-oriented anticline with steeper dips on its northwestern flank (Ayyad and Darwish, 1996). The Goliath-1 well was drilled in 1996 targeting the Lower Cretaceous clastic sequence which had multiple oil reservoirs in the nearby Mango inversion structure, about $15 \mathrm{~km}$ to the WSW (Fig. 8). The well turned out to be dry but penetrated the Lower Cretaceous down to $3200 \mathrm{~m}$. The thickening-thinning relationships within the Mesozoic-Cenozoic sequence define a Jurassic(?) to Early Cretaceous period of extensional faulting along a master fault (Fig. 10). The overlying, mostly Cenozoic sequence here also displays progressive onlap onto the apex of the anticline. Both the Mango and Goliath doubly plunging anticlines belong to the many other Syrian Arc I inverted structures offshore the northern Sinai with a characteristic ENE to NE strike (Fig. 8).

\subsection{An inverted "Syrian Arc II" structure in Israel: the Tamar gas field}

The giant Tamar field, with its 7-8 tcf (trillion cubic feet) biogenic gas reserves, is located in deepwater Israel (Fig. 9), and it was discovered in 2009 (Needham et al., 2017). On a depthconverted regional seismic section (Fig. 11a), the Tamar structure is a very prominent anticlinal feature, mostly, but not entirely predating the overlying Messinian evaporite sequence. In map view (Fig. 11b) the Tamar anticline has a slightly asymmetric closure trending SW-NE. The prominent NW-SE-striking "piano-key" faults (Kosi et al., 2012) crosscutting the anticline are quite typical for the entire deepwater Levant Basin. These faults are not sealing in nature as the gas-water contact (GWC) is at the same depth of $4797 \mathrm{~m}$ (Fig. 11b) across the entire Tamar gas field (Needham et al., 2017). A dip-oriented section we have constructed across the Tamar field assumes the isopachous nature of the three main reservoir intervals (Sand A, B and C) reported by Needham et al. (2017), and it reveals the subtle asymmetry of the struc- 


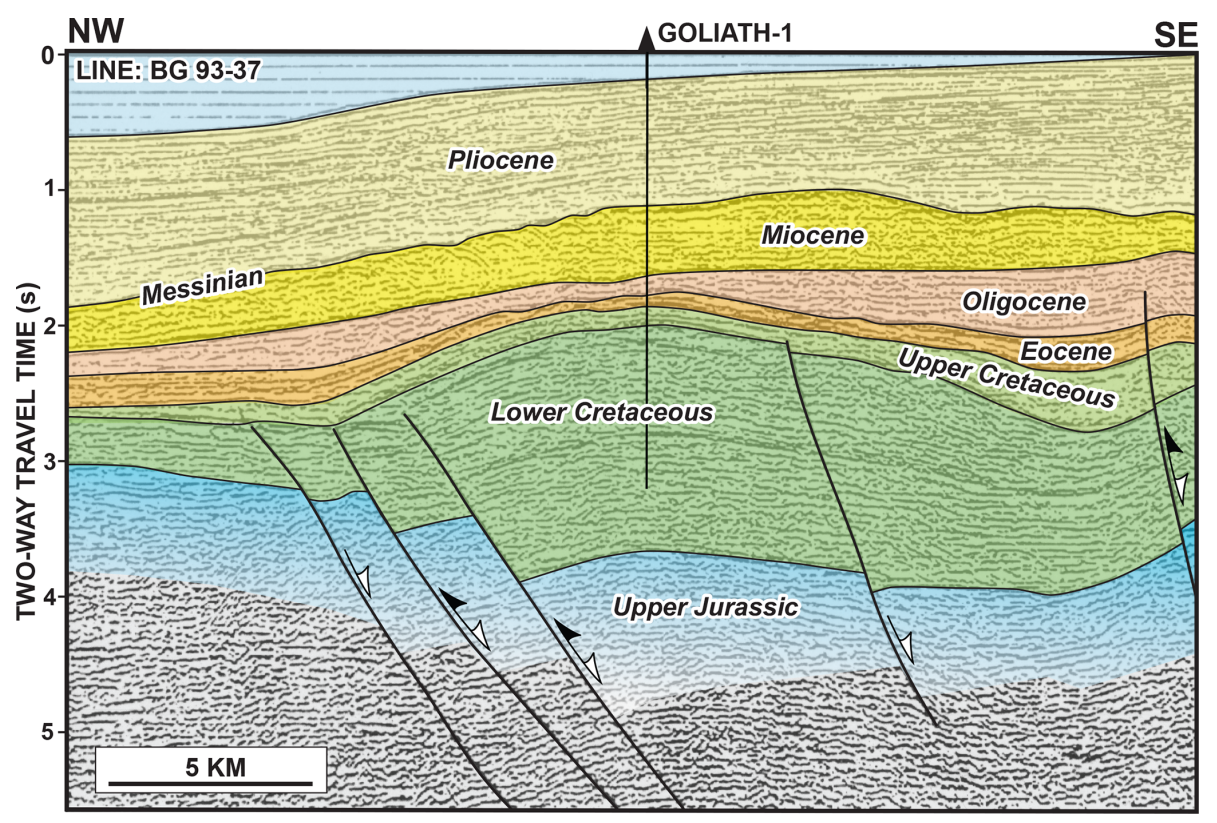

Figure 10. Two-dimensional reflection seismic profile across the Goliath anticline offshore Sinai, Egypt (see location in Fig. 8). The large syn-rift master fault controlled the deposition of the Lower Cretaceous sequence. The subsequent Late Cretaceous to Paleogene Syrian Arc inversion I is responsible for the formation of the asymmetrical anticline (adapted from Ayyad and Darwish, 1996).

ture (Fig. 11c). The slightly steeper SE flank of the anticline suggests an underlying master fault, yet the regional-scale seismic section (Fig. 11a) does not display such a fault anywhere down within the Cenozoic sequence. Similarly to the Lovászi field discussed earlier (Fig. 7), the reservoirs of the Tamar field are located stratigraphically fairly high within the structure, in the post-rift sequence. These Miocene reservoirs are located in an isopachous sequence which was deposited before the inversion took place (Fig. 11c). Since the Mesozoic (Jurassic-Early Cretaceous?) master fault responsible for the inversion is located a few kilometers beneath the Tamar anticline, its geometry is poorly defined by the seismic data (Fig. 11a). The existence of a Mesozoic syn-rift graben at depth is mostly supported by the analogy with the much better imaged and understood Syrian Arc structures located closer to the coastline (Gardosh et al., 2008, 2010, 2011; Gardosh and Tannenbaum, 2014).

\section{Case study from Atlantic Morocco: offshore anticlines of the Atlas system}

Inversion tectonics in the Atlas Mountains of Morocco was first described in the 1990s by Laville and Piqué (1992), Giese and Jacobshagen (1992), Lowell (1995), and Beauchamp et al. (1996, 1999). For the last 2 decades many other publications have been devoted to various aspects of inversion in the broader Moroccan Atlas system (Frizon de Lamotte et al., 2000, 2009; Hafid, 2000, 2006; Teixell et al.,
2003, Missenard et al., 2007; Leprêtre et al., 2018; Perez et al., 2019).

The Atlas system does not stop at the Atlantic coastline, but the large surface anticlines of the onshore Essaouira Basin and the western High Atlas of Morocco (Fig. 12) can be followed into the nearby offshore area (Hafid, 2000, 2006; Hafid et al., 2000, 2006). In fact, the signature of the Neogene to Holocene inversion of the Atlas system, as the result of African-Eurasian plate convergence, can be followed into the deepwater area as well, some $200 \mathrm{~km}$ to the west of the coastline at a water depth of $2000-4000 \mathrm{~m}$ (Fig. 12) but still located over highly extended continental crust (Tari and Jabour, 2011, 2013; Tari et al., 2012; Neumaier et al., 2016). The deepwater anticlines have a general NW-SE to WNWESE trend based on regional-scale 2D seismic reflection data sets (Fig. 12b).

These inversion anticlines, with a an average spacing of about $10-20 \mathrm{~km}$, are superposed by a much longerwavelength neotectonic arching of the Ras Tafelney Plateau (Fig. 13) described by Tari et al. (2012). The reason for this regional, about 200-300 km wide basin-scale inversion of the margin (Fig. 13) is the neotectonic shortening within the broader African-Eurasian plate boundary (Gomez et al., 2000) extending at least $200 \mathrm{~km}$ offshore from the Atlas system onshore (Fig. 12). The broad deepwater arch was termed the "Atlantic Atlas" by Benabdellouahed et al. (2017), and we regard it as a good example of basin-scale inversion.

Note that most of the prominent inversion anticlines in the onshore Essaouira Basin and the High Atlas region (Fig. 12a) have been interpreted in terms of folding detached 


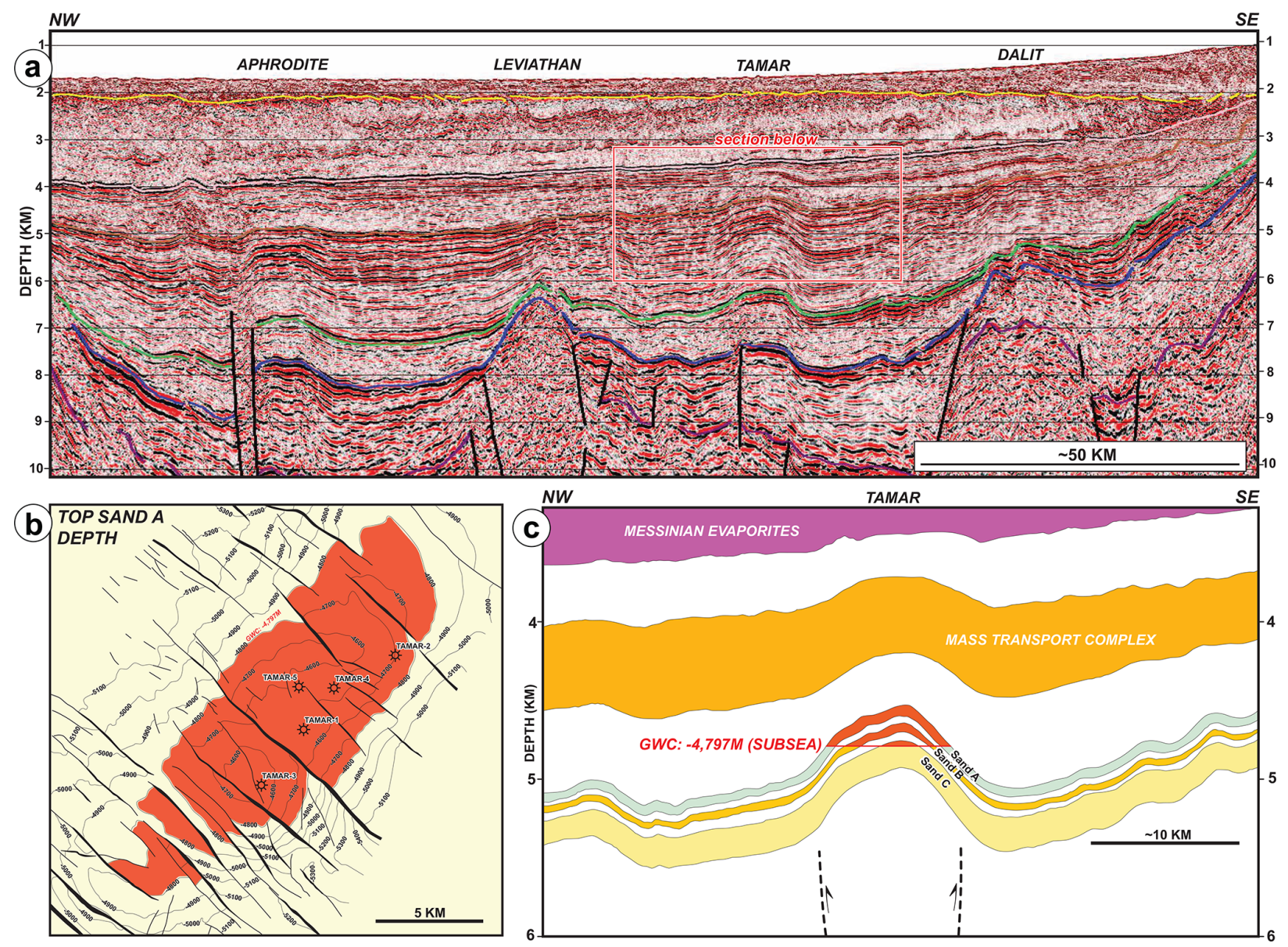

Figure 11. Highlights of the Tamar field, offshore Israel; for location, see Fig. 8. (a) Regional-scale pre-stack depth migrated seismic reflection section across the Levant Basin offshore Israel and Cyprus (Roberts and Peace, 2007). Note the large vertical exaggeration. (b) Structural depth map on the Miocene Sand A reservoir level (Needham et al., 2017). (c) Simplified cross section across the field based on Needham et al. (2017). Note the large vertical exaggeration.

on Upper Triassic to lowermost Jurassic evaporites in the region (e.g., Hafid, 2000, 2006; Verges et al., 2017; Dooley and Hudec, 2020). However, the anticlines in the deepwater area, outboard of the salt basin, are entirely controlled by basement-involved faults (Tari et al., 2012). Based on the interpretation of 3D reflection seismic data, compressionally reactivated syn-rift normal faults are responsible for these inversion structures with a corresponding detachment close to the base of the Mesozoic basin fill (Fig. 14a). This kind of inversion anticline was termed basement-involved inversion fold (Fig. 14b) by McClay et al. (2018) quoting Mount et al. (2011).

The example shown in Fig. 14a forms a robust four-way closure as the result of inversion tectonics, like many others along the basinward edge of the salt basin (Fig. 13), making it a hydrocarbon exploration target. The bright reflectors within the mid-Jurassic sequence (Fig. 14a) were interpreted corresponding to a basin floor fan (Fig. 14a), and this exploration target was drilled in 2014 (Tari et al., 2017b). The
Mazagan-1 (MZ-1) well turned out to be a dry hole, for reasons other than finding a valid hydrocarbon trap.

\section{The impact of inversion tectonics on petroleum systems and exploration efforts}

While numerous publications are devoted to the structural geology of inversion, there are only a few papers which have tried to generalize the impact of inversion tectonics on petroleum systems (e.g., Macgregor, 1995; Turner and Williams, 2004; Cooper and Warren, 2010, 2020; Bevan and Moustafa, 2012). Looking at Bally's cartoon (Fig. 1) it is intuitive to assume that there has to be an optimum "Goldilocks Zone" of inversion tectonics from a petroleum exploration point of view. However, this optimum is not simply a function of the trap size but also a function of the complex interaction between the source, reservoir and seal rocks via hydrocarbon migration. 


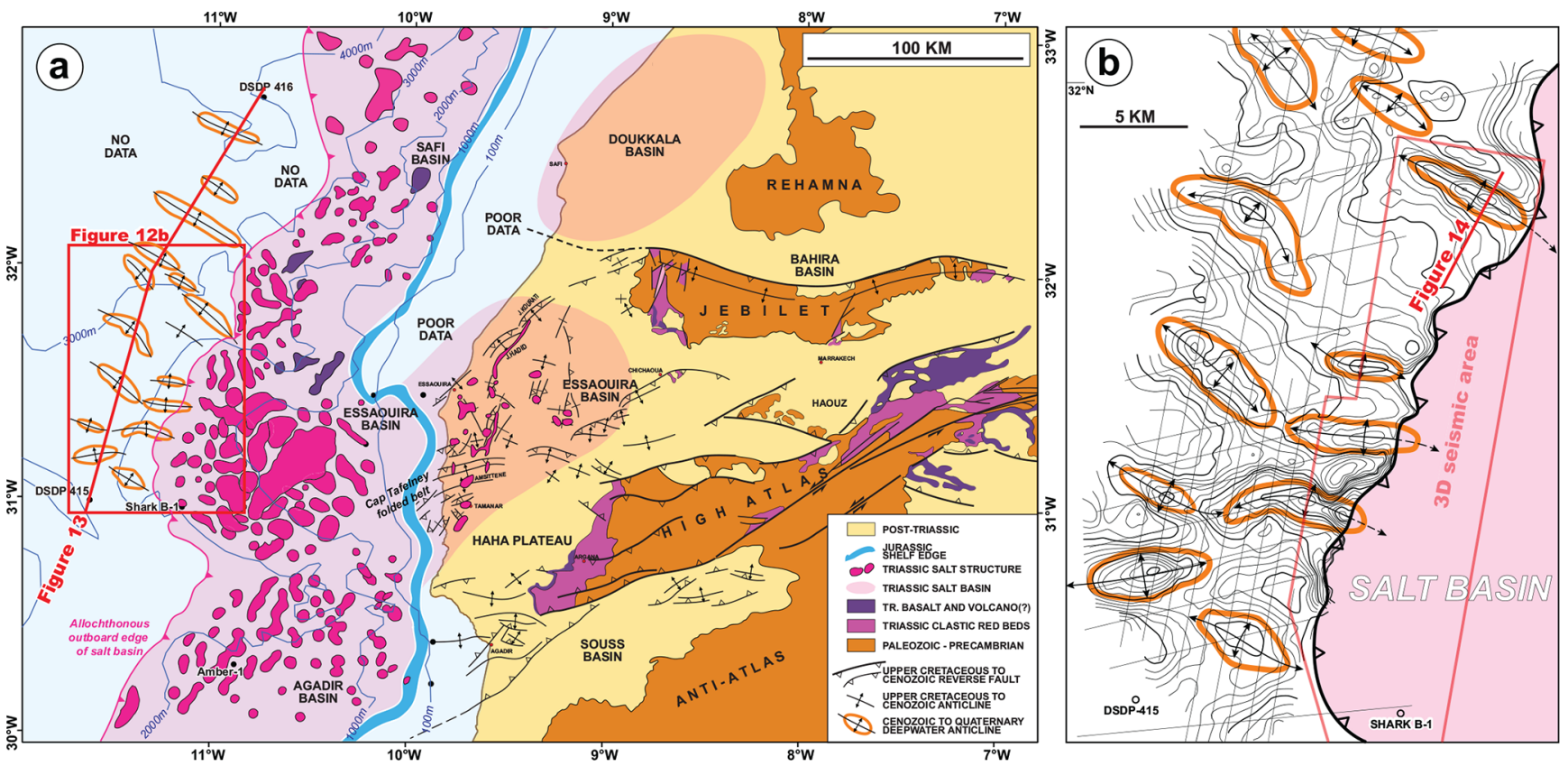

Figure 12. (a) Simplified structural map of central Atlantic Morocco, modified from Tari et al. (2017a). (b) Time structure map on a midJurassic mapping horizon using 2D seismic data located just outboard of the salt basin (shown in light magenta). The prominent late Cenozoic inversion anticlines are shown by orange outlines.

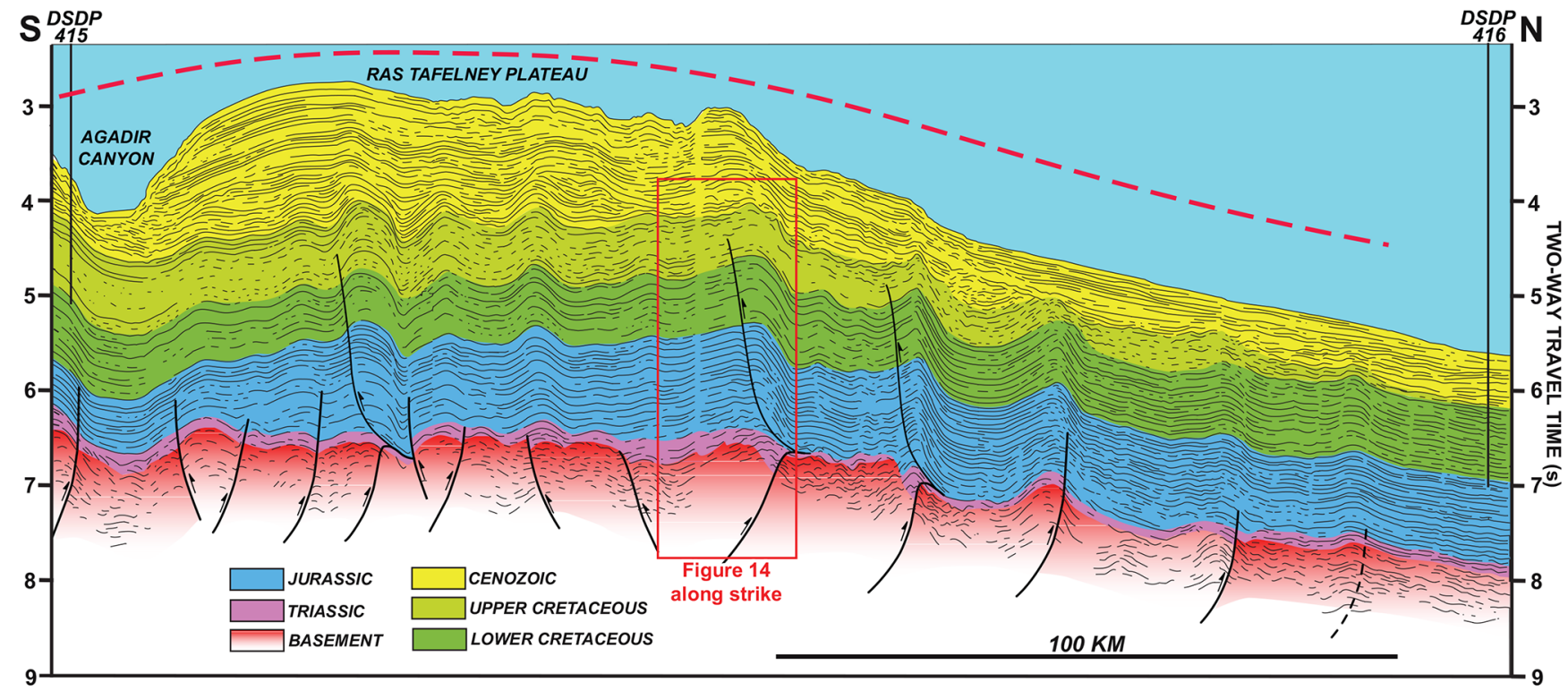

Figure 13. Line drawing interpretation of a composite regional 2D seismic transect adapted from Tari et al. (2012). Line drawing interpretation of a regional cross section connecting the DSDP 415 and 416 wells. Note the expression of middle to late Cenozoic inversion which is driven by the compressive reactivation of basement-involved normal faults and linked detachments within the Mesozoic basin cover. The dashed red line shows the regional for the upwarping of the offshore continuation of the Atlas system. The approximate location of a nearby industry 3D seismic section (Fig. 14) is highlighted by a red rectangle. 


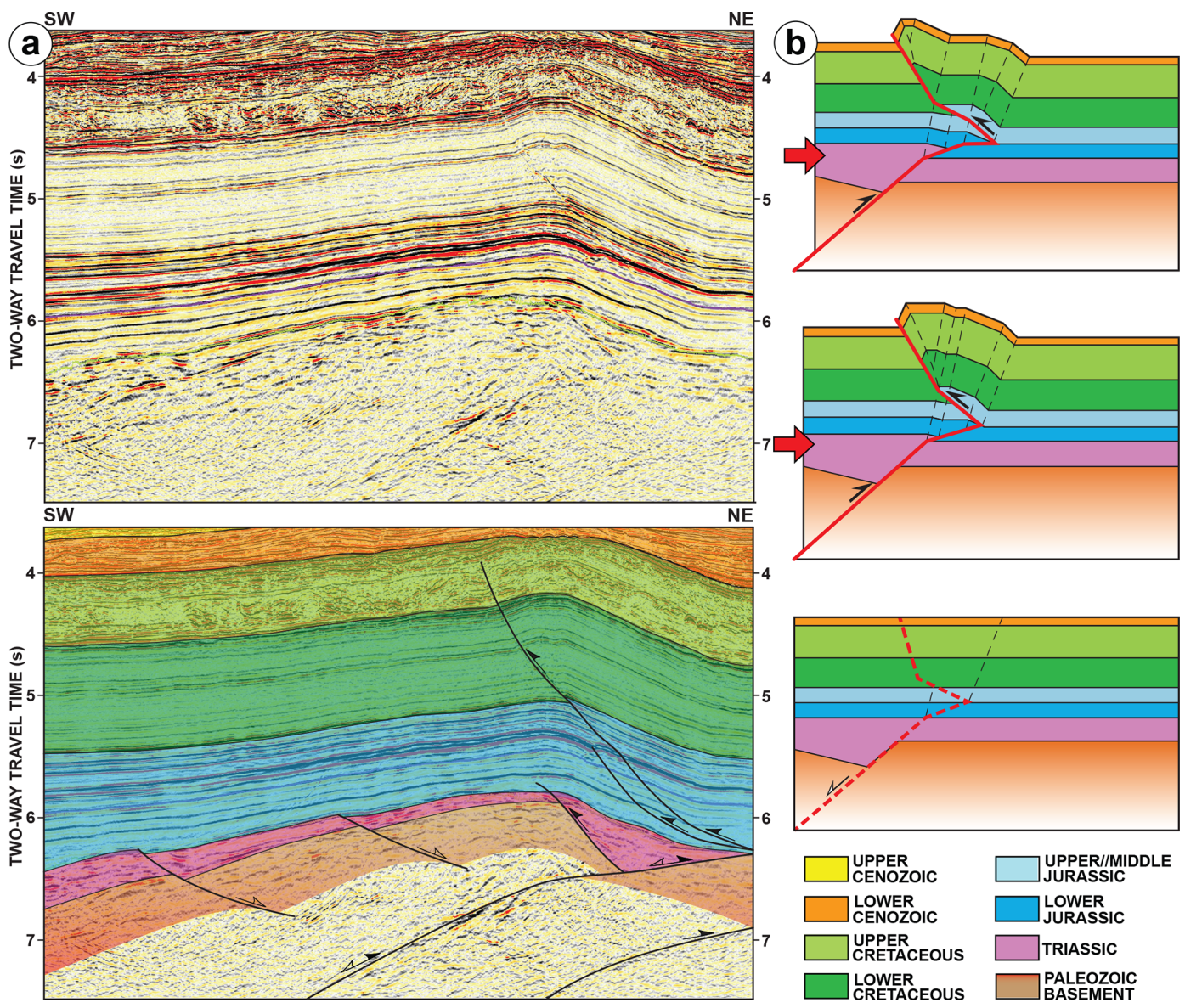

Figure 14. (a) Dip-directed 3D seismic reflection seismic line across one of the inversion anticlines in deepwater Morocco; for location, see Figs. 12b and 13b. The formation of a basement-involved inversion fold adapted and slightly modified from McClay et al. (2019). This structural model is the explanation for the somewhat unusual inversion geometry for some of the deepwater anticlines in the Ras Tafelney Plateau area, offshore Morocco (Fig. 13).

From a strictly petroleum system point of view the positive connotation of inversion tectonics in the petroleum industry is largely due to the trap and the reservoir development, i.e., robust closures with reservoirs in them as the synrift basin fill tends to accumulate reservoirs. In contrast, the negative connotation of inversion tectonics is based mostly on its perceived impact on charging and sealing; i.e., the uplift shuts down generation in the syn-rift source kitchen and the ongoing deformation tends to lead to breaching and exhumation.

The summary below is largely based on the work of Bevan and Moustafa (2012), who used the examples of three onshore Egyptian fields (e.g., Razzak, Mubarak and Kattaniya) to generalize some observations. We note that these cases specifically capture the lessons from inverted structures in a failed wide rift setting in an onshore basin where the postrift basin fill is very thin, especially compared to the syn-rift sequence (Fig. 15).

Inversion structures which are relatively mild develop lowamplitude but robust four-way closures in the hanging wall of the master fault responsible for the structure (Fig. 15a). The master fault does not necessarily have to manifest itself at the level of the reservoirs. As described earlier in the case of the Lovászi and Tamar fields, inverted structures could have large closures higher up in the unfaulted sequence (Figs. 7 and 11, respectively). As to charge, the position of source and seal rocks in the hanging wall side of the fault is quite critical. Whereas the hydrocarbons generated in the source rocks located deep beneath the inversion anticline may migrate updip towards the flexural margin from the structure, the source rocks at the faulted margin may generate hydrocarbons which then migrate up along the fault plane to the ultimate trap in the apex (Fig. 15a).

In the more advanced inverted structure (Fig. 15b) the same basic charge limitation occurs; i.e., the majority of mature hydrocarbons from within the source rocks within the deeper syn-rift sequence will migrate away from the hanging wall closure associated with the reactivation of the master fault. However, the smaller closures that could develop above antithetic faults, or detached on salt on the subsidiary side 

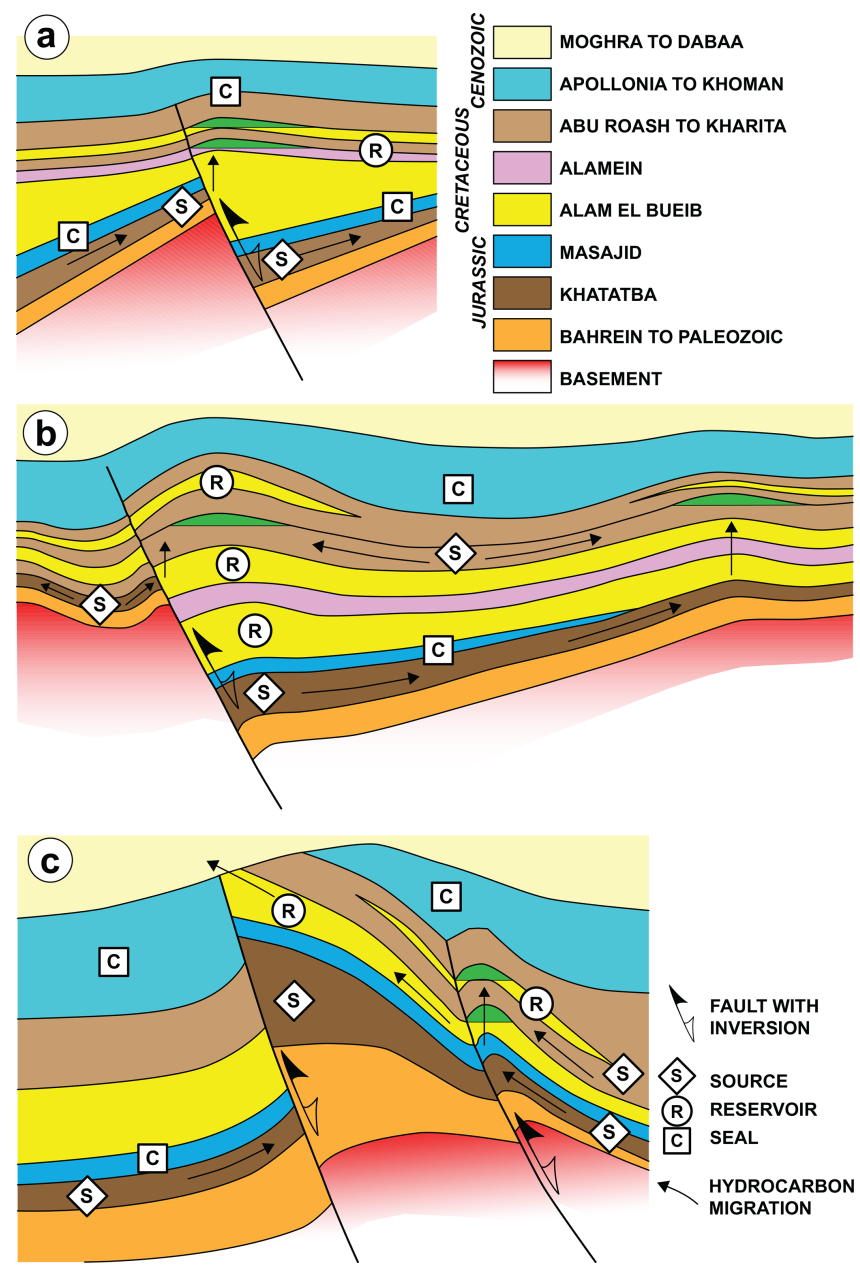

Figure 15. Cartoons of potential charge scenarios of structures associated with inversion structures, redrawn from Bevan and Moustafa (2012). These examples from the Western Desert of Egypt illustrate well the increasing severity of inversion with the corresponding variations in the petroleum system migration patterns. The three progressive stages are shown using the oil field examples of (a) Razzak, (b) Mubarak and (c) Kattaniya. See text for a generalization of the impact of inversion tectonics on petroleum systems and exploration efforts.

of the half-graben (Fig. 1e), may receive charge (Fig. 15b). This asymmetric arrangement of traps associated with nearnull-point inversion is informally called the butterfly structure (see Fig. 1e).

In the most advanced cases of structural inversions (Fig. 15c), the reservoir units in the hanging wall become uptilted and potentially exposed on the paleo-surface, therefore becoming breached. As noted by many, the vertical uplift of source rocks, potentially generating hydrocarbons prior to the inversion, may switch off the kitchen as the source rocks may reach shallower depths where they are not generating any more (e.g., Turner and Williams, 2004; Cooper and Warren, 2010). In these more severe cases of inversion, the smaller, subsidiary structures on the flank should be targeted (Fig. 15c). These smaller closures may remain unbreached and could receive charge from downdip source rocks, as Bevan and Moustafa (2012) pointed out.

The Western Desert also provides important additional insights into the positive aspects of inversion. Bosworth and Tari (2020) describe a case study where intervening periods of inversion in multiphase extensional basins turned out to be a key to having excellent exploration targets.

As to modeling the hydrocarbon charge history in inversion structures, especially those associated with multistep deformations, it is clearly a difficult 4D challenge. In a case study of the Wytch Farm field, Neumaier et al. (2017) were able to explain the exceptional oil charge in this large field as opposed to many other adjacent inversion structures. However, for this modeling, numerous steps are required which are typically not parts of basin modeling efforts on more "standard" fields. These extra modeling steps included pre-inversion drainage area-based oil migration analysis, petroleum system modeling of the duration of the localized "charge window", cross-fault charge amounts and rates.

Another unique phenomenon associated with inversion is the fault-valve action described by Sibson (1995). The selective reactivation of preexisting normal faults as reverse faults could be due to fluid overpressures developed during inversion. The significant overpressure can trigger the compressional reactivation of moderately to steeply dipping faults. Therefore, episodes of vertical hydrocarbon remigration of hydrocarbons from lower reservoir levels to higher ones are quite likely to occur along the reverse faults bounding the inversion structure (Sibson, 1995). In an extreme case, however, this repeated process can breach an existing petroleum accumulation.

As to the regional-scale impact of structural inversion we reiterate here the simple point made by Tari and Jabour (2011). The large gas discoveries of the last decade in the deepwater Levant Basin are all associated with inverted structures which strike parallel to the margin (Fig. 8). From a trapping point of view this translates into an optimum situation as the closures of the four-way anticlines are not significantly affected by the regional basinward dip trending perpendicular to the anticlinal axes (Fig. 16). In contrast, on passive margins where the inversion anticlines have the same trend as the regional dip, the four-way closures on the updip end of the structures tend to be much smaller (Fig. 16). The anticlines in the central segment of Atlantic Morocco have a general WNW-ESE trend (Fig. 12), perpendicular to the overall strike of the passive margin but parallel with the regional dip of the margin. Therefore, we believe that the regional-scale trend of the inverted structures versus the regional dip in a passive continental margin or in a foredeep setting is quite important (Tari and Jabour, 2011). 

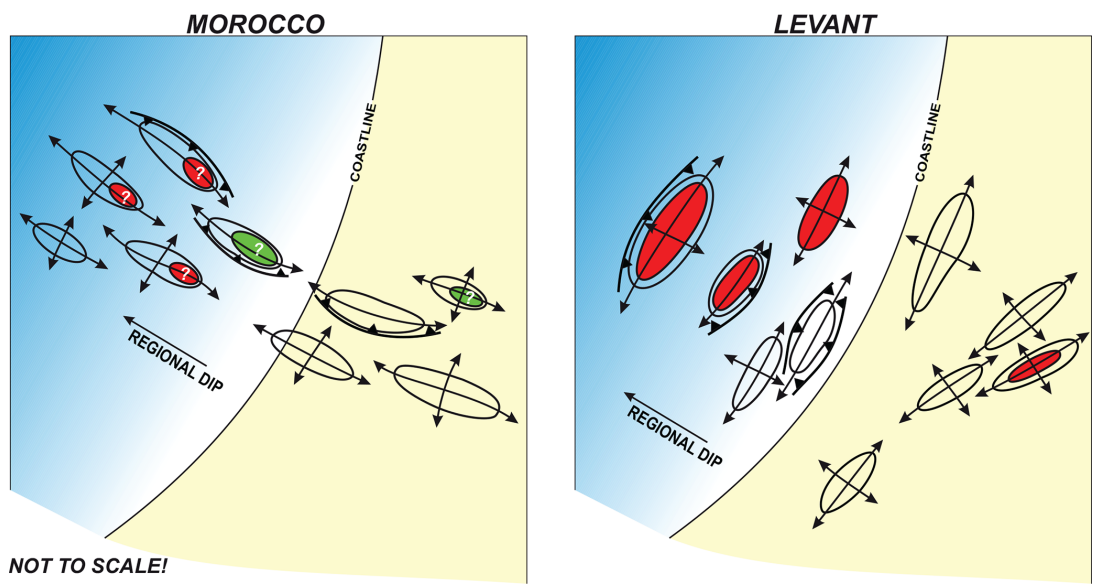

Figure 16. The impact of the trend of inverted structures versus the regional dip, adapted from Tari and Jabour (2011). From a trapping point of view, if inversion structures strike perpendicular to the regional dip in a basin, then this translates into an optimum situation as to the size of the four-way closures of the anticlines. In contrast, in a basin where the inversional anticlines have the same trend as the regional dip, the four-way closures on the updip end of the structures tend to be much smaller.
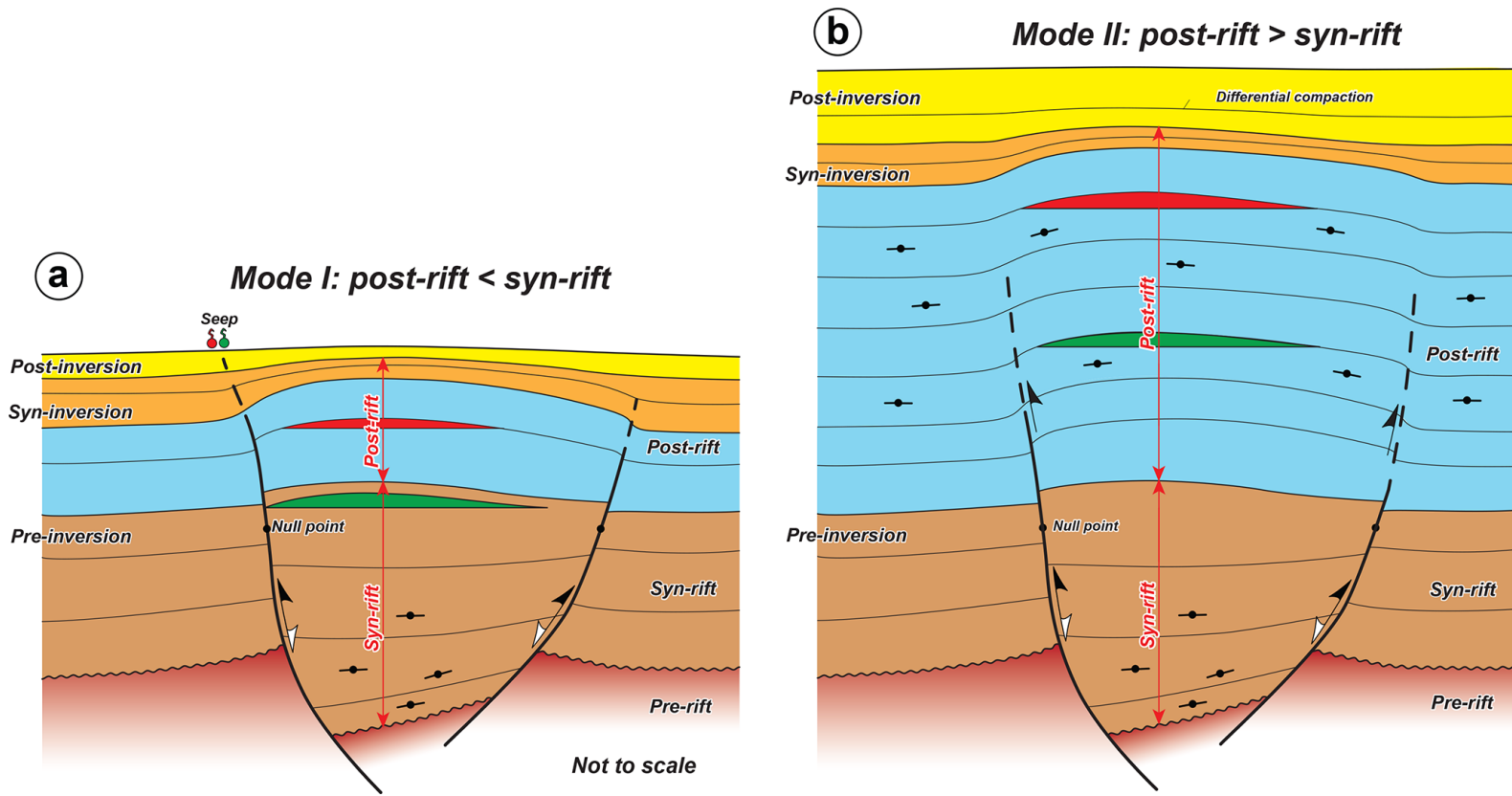

Figure 17. Subdivision of inversion structures into two modes of inversion. A structure develops in Mode I inversion if the syn-rift succession in the preexisting extensional basin unit is thicker than its pre- and syn-inversion parts of its post-rift cover. In contrast, a structure evolves in Mode II inversion if the opposite syn- versus post-rift (pre- and syn-inversion) sequence thickness ratio can be observed. These two modes have different impacts on the petroleum system elements in any given inversion structure.

\section{Two modes of inversion tectonics: petroleum exploration implications}

While inversion tectonics can produce spectacular traps, inversion tectonics is a process which has profound implications on other elements of the petroleum systems and, therefore, the hydrocarbon prospectivity, both in a positive and a negative sense (e.g., Macgregor, 1995; Turner and Williams, 2004; Cooper and Warren, 2010, 2020). The most negative impact is attributed to the fact that during inversion, source rock sections are brought closer to the paleo-surface and therefore previous mature source rocks switch off and become non-generative. Also, the main reservoir and source rock sections are brought to the near-surface and therefore breached (Fig. 17a). There are many other negative but valid impacts listed by Turner and Williams (2004), giving the impression that inverted features may be more challenging for exploration than "regular" anticlines formed by simple 
contraction. Perhaps their view might also be somewhat biased by considering examples from exhumed European Atlantic margins (e.g., Doré et al., 2002). In these regionally inverted rift basins there is plenty of evidence for underfilled fields and former petroleum accumulations which were breached and leaked away due to inversion tectonics (Turner and Williams, 2004). In particular, the Wessex Basin (Underhill and Stoneley, 1998) provides a very well-studied example of this process. As Neumaier et al. (2017) demonstrated, the petroleum charge in this basin has been successful only for the very large Wytch Farm and a series of smaller satellite traps along a fill-spill chain to the west but did not work anywhere else.

Yet, in many other basins of the world, inverted structures provide repeatable and highly successful plays. In particular, some of the examples we chose for this paper, located in the Sava Folds region of the western Pannonian Basin and the Syrian Arc II anticlines in the deepwater Levant Basin, turned out to be very successful.

We believe that the key for the success in these basins is that source rocks are not constrained to the extensional basin fill beneath but rather occupy a higher and broader post-rift, but pre-inversion stratigraphic position (Fig. 17b). These post-rift source rocks tend to be more regional in character and can have the right depth within the hydrocarbon generation window as opposed to the much deeper syn-rift source rocks which are spent and cannot expel anymore. Given the position of the active source rock sequence in the lower Miocene to Oligocene post-rift basin fill in the Tamar field example (Gardosh and Tannenbaum, 2014), the hydrocarbon generation could be assumed regionally and the inversion anticlines become the focus of the ongoing lateral and vertical charge. These structures can therefore be more successful at shallower reservoir levels within the post-rift succession.

Due to the observational evidence, we suggest that examples of inversion tectonics represent two main modes of evolution (Fig. 17). Mode I is the more widely recognized classic case, where the syn-rift succession is overlain by a relatively thin post-rift cover including pre-, syn- and post-inversion units (Fig. 17a). This could be the result of a relatively short time period between the end of extension and the onset of contraction. Cooper and Warren (2020) using recently provided evidence for an early observation by Mike Coward to show that inversion does indeed appear to be favored by a relatively short time interval between the extensional and compressional phases. Another reason for a preexisting extensional basin unit that is thicker than its post-rift cover could be a low sedimentation rate due to limited accommodation space and/or sediment supply.

In contrast, inversion anticlines developed in the so far underappreciated Mode II have the opposite proportions; i.e., the post-rift sequence is thicker than the underlying syn-rift (Fig. 17b). This might be due to a longer time interval between the extension and contraction, but it may also reflect
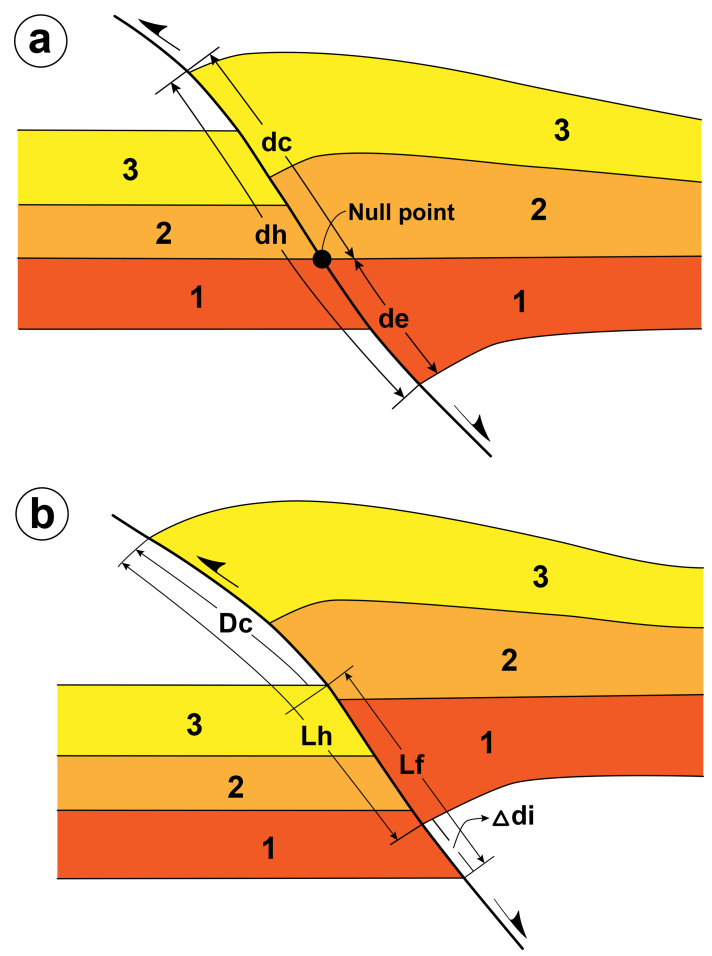

Figure 18. Two methods to determine the inversion ratio in a quantitative manner by (a) Williams et al. (1989) and (b) Song (1997). In our view, the quantification of inversion tectonics remains a challenge as the deeper section beneath an inversion anticline is typically not well imaged seismically and/or not drilled due to the greater depth. Therefore, a more practical approach is needed to describe inversion tectonics in cases where not all the required geometric elements of a structure can be measured due to subsurface data constraints.

high sedimentation rates due to large sediment supply and accommodation space. Importantly, the contractionally reactivated faults do not propagate through the entire post-rift basin fill, and therefore Mode II structures manifest themselves typically as buckle folds at higher stratigraphic levels (e.g., Tamar Anticline, Fig. 11).

In general, we tentatively attribute the grouping of inversion structures in these two modes to their regional geodynamic setting. Mode I structures are likely to be associated with failed intracontinental rifts (e.g., the North Sea) and proximal passive margins (e.g., offshore the Sinai shelf margin). Some of these structures may also have experienced regional-scale exhumation which prevented prolonged postrift sedimentation (e.g., the Wessex Basin). Mode II structures appear to be found in back-arc basins (e.g., the Pannonian Basin) and in distal parts of passive margins (e.g., the deepwater Levant Basin). Folded belts and their foredeeps may have either Mode I or II inversion examples depending on the precursor rift basins incorporated into the subsequent contractional deformation. 


\section{Quantifying inversion: limitations of the existing methods}

Finally, we would like to emphasize the need to better quantify the degree of inversion for any given structure in order to find the optimum trapping situation for exploration efforts on a global scale. In other words, what degree of inversion has provided the largest number of hydrocarbon fields worldwide? This analysis requires a quantitative description of the inversion, and there are two ways of doing this (Fig. 18). Williams et al. (1989) introduced the concept of inversion ratio, i.e., the magnitude of contraction due to the inversion versus the magnitude of extension. In seismic profiles, this is equivalent to the ratio between the thickness of syn-rift deposits above the null point parallel to the fault plane and the total thickness of syn-rift deposits parallel to the fault plane on the hanging wall (Fig. 18a). However, the inversion ratio may be difficult to calculate in cases when the null point cannot be located with confidence. An alternative method was proposed by Song (1997) to calculate the inversion ratio (Fig. 18b), but this method also requires a good handle on many elements of the stratal geometry along the master fault (e.g., Yang et al., 2011).

In our experience, the quantification of inversion degree is a challenge as the deeper section beneath an inversion anticline is typically not well imaged seismically and/or not drilled due to the greater depth. It is quite typical in exploration projects not have all the geometric parameters necessary for calculating the inversion ratio for any given structure (Fig. 18). For example, the inversion ratio cannot be determined with confidence in most of the case studies described in this paper, i.e., the Budafa, Lovászi and Tamar structures (Figs. 5, 7 and 11, respectively), due to the poor understanding of the underlying extensional basins. Therefore, a more practical approach is needed to describe inversion tectonics in cases where not all the geometric elements of a structure can be measured due to subsurface data constraints. This may be especially true for Mode II inversion structures.

\section{Conclusions}

Inversion structures provide a range of traps for petroleum exploration. The most preferred petroleum exploration targets are mild to moderate inversion structures with relatively small vertical-amplitude, simple map-view expression. The hydrocarbon traps in these structures cluster above the extensional depocenters closer to the faulted margin and are typically well imaged on seismic reflection data. Cases of strong or multiple inversion are not considered ideal for exploration, mostly due to leakage or breaching. Besides seal failure, multiple migration episodes may also result in underfilled traps. As syn-rift source rock units may be uplifted above the generation window, the hydrocarbon charge may become reduced or terminated. Severe cases of inversion may also translate into reflection seismic imaging challenges associated with the complex trap(s).

For any particular structure the evidence for inversion is typically provided by subsurface data sets such as reflection seismic and well data. However, in many cases the deeper segments of the structure are either poorly imaged by the seismic data and/or have not been penetrated by exploration wells. In these cases the interpretation of any given structure in terms of inversion has to rely on the regional understanding of the basin evolution with evidence for an early phase of substantial crustal extension by normal faulting. In some cases, where the regional geology has not been properly appreciated, the simple reactivation of preexisting structures related to earlier episodes of shortening was erroneously classified as inversion.

The sometimes negative perception of inversion is due to the fact that there are not that many successful examples described globally. Only about $3 \%$ of the traps of hydrocarbon fields with reverse faulting or overthrusting are reported to be associated with inversion (Fig. 2). We believe that this number should be significantly higher as many inverted structures may not be recognized as such. A statistically driven global data mining approach, establishing observationally the most optimal degree of structural inversion for hydrocarbon exploration, appears to be missing to date.

There might be a negative bias towards the prospectivity of inverted structures using examples from exhumed margins. Another bias may stem from the typical assumption that the generating kitchen tends to be in the syn-rift sequence of the inverted structure. Successful exploration cases in basins which have not experienced uplift and exhumation, like the giant gas discoveries in the deepwater Levant Basin, highlighted the importance of the source, reservoir and seal rocks not being constrained to the syn-rift basin fill. In these cases, all these elements of the petroleum system are located in the regional post-rift pre-inversion sequence.

Inversion structures should be classified in two modes, depending on the relative ratio of the syn-rift versus post-rift strata (up to the stratigraphic level of the latest significant inversion event). Mode I corresponds to the classic inversion structures, i.e., the reverse-fault-bounded "Sunda folds", dominated by a thick syn-rift basin fill with a relatively thin post-rift sequence at the time of inversion. In contrast, Mode II structures develop when inversion occurs after the deposition of a thicker post-rift sequence than the syn-rift basin fill in the underlying extensional structure. In this case buckle folds tend to develop in the post-rift pre-inversion sequence. Cases of Mode I inversion tend to develop in failed intracontinental rifts and proximal passive margins, and Mode II structures appear to be found in back-arc basins and in distal parts of passive margins.

Data availability. Some of the seismic lines used in this study are confidential and not available publicly. 
Author contributions. GT wrote the text and compiled the paper, DA analyzed the IHS Markit global database, ZS provided structural geology expertise, and TT supplied 3D reflection seismic and well data from SW Hungary.

Competing interests. The authors declare that they have no conflict of interest.

Special issue statement. This article is part of the special issue "Inversion tectonics - 30 years later". It is a result of the EGU General Assembly 2019, Vienna, Austria, 7-12 April 2019.

Acknowledgements. We are pleased to thank Jonas Kley and Piotr Krzywiec for inviting us to contribute this paper to the special issue of Solid Earth and for their editorial efforts. We are grateful to IHS Markit for the access to their extensive worldwide exploration and production database in order to find reported cases of inverted traps. Discussions about inversion tectonics with Albert Bally, Bill Bosworth, Joan Flinch, Mohammad Hafid, Frank Horváth, Haddou Jabour, Hans-Gert Linzer, Paul Lyon and Juan Ignacio Soto are also acknowledged. Mark Rowan, Bill Bosworth, Michael Gardosh and Gábor Bada provided very detailed, insightful and constructive reviews. Peter Pernegr kindly drafted some of the figures. This paper is dedicated to the memory of Albert W. Bally (19252019), who was the PhD Advisor of the first author at Rice University, Houston, Texas.

Review statement. This paper was edited by Piotr Krzywiec and reviewed by William Bosworth, Michael Gardosh, Gábor Bada, and Mark Rowan.

\section{References}

Amilibia, A., McClay, K. R., Sabat, F., Muñoz, J. A., and Roca, E.: Analogue modelling of inverted oblique rift systems, Geol. Acta, 3, 251-271, 2005.

Ayyad, M. H. and Darwish, M.: Syrian Arc structures, a unifying model of inverted basins and hydrocarbon occurrences in North Egypt, Proceedings of the 13th Egyptian General Petroleum Corporation Exploration and Production Conference, Cairo, Egypt, 21-24 October 1996, 1, 40-59, 1996.

Bada, G., Horváth, F., and Fejes, I.: Review of the present day geodynamics of the Pannonian basin: progress and problems, J. Geodyn., 27, 501-527, 1999.

Bada, G., Horvath, F., Cloetingh, S., and Coblentz, D. D.: Role of topography-induced gravitational stresses in basin inversion: the case study of the Pannonian basin, Tectonics, 20, 343-363, 2001.

Bada, G., Horváth, F., Dövenyi, P., Szafián, F., Windhoffer, G., and Cloetingh, S.: Present-day stress fields and tectonic inversion in the Pannonian basin, Global Planet. Change, 58, 165-180, 2007.

Badley, M. E., Price, J. D., and Backshall, L. C.: Inversion, reactivated faults and related structures: seismic examples from the southern North Sea, in: Inversion tectonics, edited by: Cooper,
M. A. and Williams, G. D., Geological Society, London, UK, Geol. Soc. Spec. Publ., 44, 201-219, 1989.

Bally, A. W.: Tectogénèse et sismique réflexion, B. Soc. Geol. Fr., Serie 7, 29, 279-285, 1984.

Bally, A. W. and Snelson, S.: Realms of subsidence, in: Facts and Principles of World Petroleum Occurrence, edited by: Miall, A. D., Canadian Society Petroleum Geologists Memoir, 6, 9-94, 1980.

Bevan, T. G. and Moustafa, A. R.: Inverted rift-basins of northern Egypt, in: Regional Geology and Tectonics: Phanerozoic Passive Margins, Cratonic Basins and Global Tectonic Maps, edited by: Roberts, D. G., and Bally, A. W., Elsevier, Amsterdam, the Netherlands, 483-507, https://doi.org/10.1016/b978-0444-56356-9.00018-3, 2012.

Beauchamp, W., Barazangi, M., Demnati, A., and Alji, M. E.: Intracontinental rifting and inversion: Missour basin and Atlas mountains, Morocco, AAPG Bull., 80, 1459-1481, 1996.

Beauchamp, W., Allmendinger, R. W., Barazangi, M., Demnati, A., El Alji, M., and Dahmani, M.: Inversion tectonics and the evolution of the High Atlas Mountains, Morocco, based on a geological-geophysical transect, Tectonics, 18, 163-184, 1999.

Benabdellouahed, M., Klingelhoefer, F., Gutscher, M. A., Rabineau, M., Biari, Y., Hafid, M., Duarte, J. C., Schnabel, M., Baltzer, A., Pedoja, K., and Le Roy, P.: Recent uplift of the Atlantic Atlas (offshore West Morocco): Tectonic arch and submarine terraces, Tectonophysics, 706, 46-58, 2017.

Bonini, M., Sani, F., and Antonielli, B.: Basin inversion and contractional reactivation of inherited normal faults: A review based on previous and new experimental models, Tectonophysics, 522523, 55-88, 2011.

Bosworth, W. and Tari, G.: Hydrocarbon accumulation in basins with multiple phases of extension and inversion: examples from the Western Desert (Egypt) and the Western Black Sea, Solid Earth Discuss., https://doi.org/10.5194/se-2020-105, in review, 2020.

Bosworth, W., Guiraud, R., and Kessler, L. G.: Late Cretaceous (ca. $84 \mathrm{Ma}$ ) compressive deformation of the stable shelf of northeast Africa (Egypt); far-fi eld stress effects of the "Santonian event" and origin of the Syrian arc, Geology, 27, 633-636, 1999.

Bosworth, W., El-Hawat, A. S., Helgeson, D. E., and Burke, K.: Cyrenaican "shock absorber" and associated inversion strain shadow in the collision zone of northeast Africa, Geology, 36, 695-698, 2008.

Buchanan, J. G. and Buchanan, P. G.: Basin Inversion, Geol. Soc. Spec. Publ., 88, Geological Society, London, UK, 596 pp., ISBN13 978-1-8977-9929-1, 1995.

Buchanan, P. G. and McClay, K. R.: Sandbox experiments of inverted listric and planar fault systems, Tectonophysics, 188, 97 $115,1991$.

Buiter, S. J. H., Pfiffner, O. A., and Beaumont, C.: Inversion of extensional sedimentary basins: A numerical evaluation of the localisation of shortening, Earth Planet. Sc. Lett., 288, 492-504, 2009.

Butler, R. W. H.: The influence of pre-existing basin structure on thrust system evolution in the Western Alps, in: Inversion tectonics, edited by: Cooper, M. A. and Williams, G. D., Geological Society, London, UK, Geol. Soc. Spec. Publ., 44, 105-122, https://doi.org/10.1144/gsl.sp.1989.044.01.07, 1989. 
Cartwright, J. A.: The kinematics of inversion in the Danish Central Graben, in: Inversion tectonics, edited by: Cooper, M. A. and Williams, G. D., Geological Society, London, UK, Geol. Soc. Spec. Publ., 44, 153-175, https://doi.org/10.1144/gsl.sp.1989.044.01.10, 1989.

Cloetingh, S., Bada, G., Matenco, L., Lankreijer, A., Horváth, F., and Dinu, C.: Modes of basin (de)formation, lithospheric strength and vertical motions in the Pannonian-Carpathian system: inferences from thermo-mechanical modelling, Geol. Soc. Mem., 32, Geological Society, London, UK, 32, 207-221, 2006.

Cloetingh, S., Beekman, F., Ziegler, P. A., van Wees, J. D., and Sokoutis, D.: Post-rift compressional reactivation potential of passive margins and extensional basins, in: The Nature and Origin of Compression in Passive Margins, edited by: Johnson, H., Doré, A. G., Gatliff, R. W., Holdsworth, R., Lundin, E. R., and Ritchie, J. D., Geological Society, London, UK, Geol. Soc. Spec. Publ., 306, 27-70, https://doi.org/10.1144/sp306.2, 2008.

Cooper, M. A. and Warren, M. J.: The geometric characteristics, genesis and petroleum significance of inversion structures, in: Continental Tectonics and Mountain Building: The Legacy of Peach and Horne, edited by: Law, R. D., Butler, R. W. H., Holdsworth, R. E., Krabbendam, M., and Strachan, R. A., Geological Society, London, UK, Geol. Soc. Spec. Publ., 335, 827846, https://doi.org/10.1144/sp335.33, 2010.

Cooper, M. A. and Warren, M. J.: Inverted fault systems and inversion tectonic settings, in: Regional Geology and Tectonics, Volume 1: Principles of Geologic Analysis, edited by: Scarselli, N., Adam, J., Chiarella, D., Roberts, D. G., and Bally, A. W., Elsevier, Amsterdam, 169-204, https://doi.org/10.1016/b978-0444-64134-2.00009-2, 2020.

Cooper, M. A. and Williams, G. D.: Inversion tectonics, Geol. Soc. Spec. Publ. 44, Geological Society, London, UK, 375 pp., 1989.

Cooper, M. A., Williams, G. D., de Graciansky, P. C., Murphy, R. W., Needham, T., de Paor, D., Stoneley, R., Todd, S. P., Turner, J. P., and Ziegler, P. A.: Inversion tectonics - a discussion, in: Inversion tectonics, edited by: Cooper, M. A. and Williams, G. D., Geological Society, London, UK, Geol. Soc. Spec. Publ., 44, 335-347, 1989.

Cooper, M. A., Addison, F. T., Alvarez, R., Coral, M., Graham, R. H., Hayward, A. B., Howe, S., Martinez, J., Naar, J., Penas, R., Pulham, A. J., and Taborda, A.: Basin development and tectonic history of the Llanos Basin, Eastern Cordillera, and Middle Magdalena Valley, Colombia, Am. Assoc. Pet. Geol. Bull., 79, 1421-1443, https://doi.org/10.1306/7834d9f4-172111d7-8645000102c1865d, 1995.

Dank, V.: Hydrocarbon exploration in Hungary, in: Neogene Mineral Resources in the Carpathian Basin, edited by: Hála, J., Hungarian Geological Survey, Budapest, 107-213, 1985.

Dank, V.: Petroleum Geology of the Pannonian Basin, Hungary: An Overview, in: The Pannonian Basin - a Study in Basin Evolution, edited by: Royden, L. and Horváth, F., AAPG Memoir., 45, 319 331, 1988

Davies, R., Cloke, I., Cartwright, J., Robinson, A., and Derrero, C.: Post-breakup compression of a passive margin and its impact on hydrocarbon prospectivity: an example from the Tertiary of the Faroe-Shetland Basin, United Kingdom, AAPG Bull., 88, 1-20, 2004.

De Graciansky, P. C., Dardeau, G., Lemoine, M., and Tricart, P.: The inverted margin of the French Alps and foreland basin inversion, in: Inversion tectonics, edited by: Cooper, M. A. and Williams, G. D., Geological Society, London, UK, Geol. Soc. Spec. Publ., 44, 87-104, https://doi.org/10.1144/gsl.sp.1989.044.01.06, 1989.

Dolson, J. C., Shann, M. V., Matbouly, S., Rashed, R., and Hammouda, H.: The petroleum potential of Egypt, AAPG Memoir. 73, 453-482, 2003.

Dooley, T. P. and Hudec, M. R.: Extension and inversion of salt-bearing rift systems, Solid Earth, 11, 1187-1204, https://doi.org/10.5194/se-11-1187-2020, 2020.

Doré, A. G., Corcoran, D. V., and Scotchman, I. C.: Prediction of the hydrocarbon system in exhumed basins, and application to the NW European margin, in: Exhumation of the North Atlantic Margin: Timing, Mechanisms and Implications for Petroleum Exploration, edited by: Doré, A. G., Cartwright, J. A., Stoker, M. S., Turner, J. P., and White, N. J., Geological Society, London, UK, Geol. Soc. Spec. Publ., 196, 401-431, https://doi.org/10.1144/gsl.sp.2002.196.01.21, 2002.

Dövényi, P. and Horváth, F.: Determination of contemporary crustal stress regime in Hungary, Acta Geod. Geophys. Mont. Hung., 25 , 257-266, 1990.

Druckman, Y., Gill, D., Fleischer, L., Gelbermann, E., and Wolff, O.: Subsurface geology and structural evolution of the northwestern Negev, southern Israel, Israel J. Earth Sci., 44, 115-136, 1995.

Eisenstadt, G. and Withjack, M. O.: Estimating inversion: results from clay models, in: Basin Inversion, edited by: Buchanan, J. G. and Buchanan, P. G., Geological Society, London, UK, Geol. Soc. Spec. Publ., 88, 119-136, https://doi.org/10.1144/gsl.sp.1995.088.01.08, 1995.

Eubank, R. T. and Makki, A. C.: Structural geology of the central Sumatra back-arc basin, Indonesian Petroleum Association, 10th Annual Convention, Jakarta, 26-27 May 1981, 153-196, 1981.

Eyal, Y.: Stress field fluctuations along the Dead Sea rift since the middle Miocene, Tectonics, 15, 157-170, https://doi.org/10.1029/95tc02619, 1996.

Eyal, Y. and Reches, Z. E.: Tectonic analysis of the Dead Sea Rift Region since the Late-Cretaceous based on mesostructures, Tectonics, 2, 167-185, https://doi.org/10.1029/tc002i002p00167, 1983.

Ferrer, O., McClay, K., and Sellier, N. C.: Influence of fault geometries and mechanical anisotropies on the growth and inversion of hanging-wall synclinal basins: insights from sandbox models and natural examples, in: The Geometry and Growth of Normal Faults, edited by: Childs, C., Holdsworth, R. E., Jackson, C. A.-L., Manzocchi, T., Walsh, J. J., and Yielding, G., Geological Society, London, UK, Geol. Soc. Spec. Publ., 439, https://doi.org/10.1144/sp439.8, 487-509, 2017.

Flinch, J. F. and Casas, J. M.: Inversion of a transfer system into lateral ramps: an example from the South-Central Pyrenees (Spain). Geol. Rundsch., 85, 372-379, 1996.

Freund, R., Goldberg, M., Weissbrod, T., Druckman, Y., and Derin, B.: The Triassic-Jurassic structure of Israel and its relation to the origin of the eastern Mediterranean, Israel Geological Survey Bulletin, 65, p. 26, 1975.

Frizon de Lamotte, D., Saint Bezar, B., Bracène, R., and Mercier, E.: Two step Atlas building and geodynamics of the West Mediterranean, Tectonics, 19, 740-761, 2000. 
Frizon de Lamotte, D., Leturmy, P., Missenard, Y., Khomsi, S., Ruiz, G., Saddiqi, O., Guillocheau, F., and Michard, A.: Mesozoic and Cenozoic vertical movements in the Atlas system, Tectonophysics, 475, 9-28, 2009.

Gardosh, M. A. and Druckman, Y.: Seismic stratigraphy, structure and tectonic evolution of the Levantine Basin, offshore Israel, in: Tectonic development of the Eastern Mediterranean Region, edited by: Robertson, A. H. F. and Mountrakis, D., Geological Society, London, UK, Geol. Soc. Spec. Publ., 260, 201-227, https://doi.org/10.1144/gsl.sp.2006.260.01.09, 2006.

Gardosh, M. A. and Tannenbaum, E.: The petroleum systems of Israel, in: Petroleum systems of the Tethyan region, edited by: Marlow, L. Kendall, C., and Yose, L., AAPG Memoir., 106, 179216, https://doi.org/10.1306/13431857m106298, 2014.

Gardosh, M., Druckman, Y., Buchbinder, B., and Rybakov, M.: The Levant basin offshore Israel: Stratigraphy, structure, tectonic evolution and implications for hydrocarbon exploration, Geological Survey of Israel Report, GSI/4/2008, Jerusalem, 121 pp., 2008.

Gardosh, M., Garfunkel, Z., Druckman, Y., and Buchbinder, B.: Tethyan rifting in the Levant region and its role in early Mesozoic crustal evolution, Geological Society, London, UK, Geol. Soc. Spec. Publ., 341, 9-36, 2010.

Gardosh, M., Weimer, P., and Flexer, A.: The sequence stratigraphy of Mesozoic successions in the Levant margin, southwestern Israel, A model for the evolution of southern Tethys margins, AAPG Bull., 95, 1763-1793, 2011.

Giese, P. and Jacobshagen, V.: Inversion tectonics of intracontinental ranges: High and Middle Atlas, Morocco, Geol. Rundsch., 81, 249-259, 1992.

Glennie, K. W. and Boegner, P. L. E.: Sole Pit inversion tectonics, in: Petroleum Geology of the Continental Shelf of Northwest Europe, edited by: Illing, L. V. and Hobson, G. D., Institute of Petroleum, London, UK, 110-120, 1981.

Granado, P. and Ruh, J. B.: Numerical modelling of inversion tectonics in fold-and-thrust belts, Tectonophysics, 763, 14-29, 2019.

Granado, P., Ferrer, O., Muñoz, J. A., Thöny, W., and Strauss, P.: Basin inversion in tectonic wedges: Insights from analogue modelling and the Alpine-Carpathian fold-and-thrust belt, Tectonophysics, 703, 50-68, 2017.

Gomez, F., Beauchamp, W., and Barazangi, M.: Role of the Atlas Mountains (northwest Africa) within the African-Eurasian plateboundary zone, Geology, 28, 775-778, 2000.

Guiraud, R. and Bosworth, W.: Senonian basin inversion and rejuvenation of rifting in Africa and Arabia: synthesis and implications to plate-scale tectonics, Tectonophysics, 282, 39-82, 1997.

Hafid, M.: Triassic-early Liassic extensional systems and their Tertiary inversion, Essaouira Basin (Morocco), Mar. Petrol. Geol., 17, 409-429, 2000.

Hafid, M.: Styles structuraux du Haut Atlas de Cap Tafelney et de la partie septentrionale du Haut Atlas occidental: tectonique salifere et relation entre l'Atlas et l'Atlantique. Notes et Mémoires du Service Géologique du Maroc, 465, p. 172, 2006.

Hafid, M., Ait Salem, A., and Bally, A. W.: The western termination of the Jebilet-High Atlas system (offshore Essaouira Basin, Morocco), Mar. Petrol. Geol., 17, 431-443, 2000.

Hafid, M., Zizi, M., Bally, A. W., and Salem, A. A.: Structural styles of the western onshore and offshore termination of the High Atlas, Morocco, Comptes Rendus Geoscience, 338, 50-64, 2006.
Hayward, A. B. and Graham, R. H.: Some geometrical characteristics of inversion, in: Inversion tectonics, edited by: Cooper, M. A. and Williams, G. D., Geological Society, London, UK, Geol. Soc. Spec. Publ., 44, 17-39, https://doi.org/10.1144/gsl.sp.1989.044.01.03, 1989.

Horváth, F.: Phases of compression during the evolution of the Pannonian Basin and its bearing on hydrocarbon exploration, Mar. Petrol. Geol., 12, 837-844, 1995.

Horváth, F. and Cloetingh, S.: Stress-induced late-stage subsidence anomalies in the Pannonian Basin, Tectonophysics, 266, 287300, 1996.

Horváth, F. and Tari, G.: IBS Pannonian Basin project: a review of the main results and their bearings on hydrocarbon exploration, in: The Mediterranean Basins: Tertiary Extension within the Alpine Orogene, edited by: Durand, B., Jolivet, L., Horváth, F., and Séranne, M., Geological Society, London, UK, Geol. Soc. Spec. Publ., 156, 195-213, https://doi.org/10.1144/gsl.sp.1999.156.01.11, 1999.

Horváth, F., Bada, G., Szafián, P., Tari, G., Ádám, A., and Cloetingh, S.: Formation and deformation of the Pannonian Basin: constraints from observational data, in: European Lithosphere Dynamics, edited by: Gee, D. G. and Stephenson, R. A., Geol. Soc. Mem., 32, Geological Society, London, UK, 191-206, 2006.

IHS Markit.: International Exploration and Production Database, https://ihsmarkit.com/products/data-lake.html, last access: 17 October 2020.

Jackson, C. A. L. and Larsen, E.: Temporal constraints on basin inversion provided by 3D seismic and well data: a case study from the South Viking Graben, offshore Norway, Basin Res., 20, 397-417, 2008.

Jackson, C. A. L., Chua, S. T., Bell, R. E., and Magee, C.: Structural style and early stage growth of inversion structures: 3D seismic insights from the Egersund Basin, offshore Norway, J Struct. Geol., 46, 167-185, 2013.

Juhász, G.: Comparison of the sedimentary sequences in Late Neogene subbasins in the Pannonian Basin, Hungary, Földtani Közlöny, 124, 341-365, 1994 (in Hungarian).

Juhász, G.: Lithostratigraphy of the Pannonian s.l. formations of the Neogene deep basins in Hungary, in: Stratigraphy of the geological formations of Hungary, edited by: Bérczi I. and Jámbor, Á., MOL and Hungarian Geological Society Publication, Budapest, Hungary , 469-484, 1998 (in Hungarian).

Keller, J. V. A. and McClay, K. R.: 3D sandbox models of positive inversion, in: Basin Inversion, edited by: Buchanan, J. G. and Buchanan, P. G., Geological Society, London, UK, Geol. Soc. Spec. Publ., 88, 137-146, https://doi.org/10.1144/gsl.sp.1995.088.01.09, 1995.

Krenkel, E.: Geologie der Erde, Geologie Afrikas, 1, Gebrüder Borntraeger, Berlin, Germany, 461 pp., 1925.

Kosi, W., Tari, G., Nader, F. H., Skiple, C., Trudgill, B., and Lazar, D.: Structural analogy between the "piano key faults" of deepwater Lebanon and the extensional faults of the Canyonlands grabens, Utah, United States, The Leading Edge, 31, 824-830, 2012.

Lamplugh, G. W.: Structure of the Weald and analogous tracts, Quarterly Journal of the Geological Society of London, 75, 7395 LXXIII-XCV, 1919.

Laville, E. and Piqué, A.: Jurassic penetrative deformation and Cenozoic uplift in the central High Atlas (Morocco): a tectonic 
model, structural and orogenic inversions, Geol. Rundsch., 81, 157-170, 1992.

Leprêtre, R., Missenard, Y., Barbarand, J., Gautheron, C., Jouvie, I., and Saddiqi, O.: Polyphased inversions of an intracontinental rift: case study of the Marrakech High Atlas, Morocco, Tectonics, 37 , 818-841, 2018.

Letouzey, J. L., Colletta, B., Vially, R. A., and Chermette, J. C.: Evolution of salt-related structures in compressional settings, in: Salt tectonics, a global perspective, edited by: Jackson, M. P. A., Roberts, D. G., and Snelson, S., AAPG Memoir., 65, 41-60, https://doi.org/10.1306/m65604c3, 1995.

Lowell, J. D.: Mechanics of basin inversion from worldwide examples, in: Basin Inversion, edited by: Buchanan, J. G. and Buchanan, P. G., Geological Society, London, UK, Geol. Soc. Spec. Publ., 88, 39-57, https://doi.org/10.1144/gsl.sp.1995.088.01.04, 1995.

Macgregor, D. S.: Hydrocarbon habitat and classification of inverted rift basins, in: Basin Inversion, edited by: Buchanan, J. G. and Buchanan, P. G., Geological Society, London, UK, Geol. Soc. Spec. Publ., 88, 83-93, https://doi.org/10.1144/gsl.sp.1995.088.01.06, 1995.

McClay, K. R.: Analogue models of inversion tectonics, in: Inversion Tectonics, edited by: Cooper, M. A. and Williams, G. D., Geological Society, London, UK, Geol. Soc. Spec. Publ., 44, 4159, https://doi.org/10.1144/gsl.sp.1989.044.01.04, 1989.

McClay, K. R.: The geometries and kinematics of inverted fault systems: a review of analogue model studies, in: Basin Inversion, edited by: Buchanan, J. G. and Buchanan, P. G., Geological Society, London, UK, Geol. Soc. Spec. Publ., 88, 97-118, https://doi.org/10.1144/gsl.sp.1995.088.01.07, 1995.

McClay, K., Scarselli, N., Tamara, J., Hammerstein, J., and Torres, D.: Structural styles of the Camisea fold-and-thrust belt, southeast Peru, in: Petroleum basins and hydrocarbon potential of the Andes of Peru and Bolivia, edited by: Zamora, G., McClay, K. R., and Ramos, V. A., AAPG Memoir., 117, 271-296, https://doi.org/10.1306/13622124m11750, 2018.

Missenard, Y., Taki, Z., de Lamotte, D. F., Benammi, M., Hafid, M., Leturmy, P., and Sébrier, M.: Tectonic styles in the Marrakesh High Atlas (Morocco): The role of heritage and mechanical stratigraphy, J. Afr. Earth Sci., 48, 247-266, 2007.

Mitra, S. and Islam, Q. T.: Experimental (clay) models of inversion structures, Tectonophysics, 230, 211-222, 1994.

Mount, V. S., Martindale, K. W., Griffith, T. W., and Byrd, J. O. D.: Basement-involved contractional wedge structural styles: Examples from the Hanna Basin, Wyoming, in: Thrust fault-related folding, edited by: McClay, K., Shaw, J. H., and Suppe, J., AAPG Memoir., 94, 271-281, 2011.

Moustafa, A. R.: Wrench tectonics in the north Western Desert of Egypt (Abu Roash area, southwest of Cairo), Middle East Research Centre, Ain Shams University, Earth Science Series, 2, 1-16, 1988.

Moustafa, A. R. and Khalil, M. H.: Superposed deformation in the northern Suez Rift, Egypt: relevance to hydrocarbon exploration, J. Pet. Geol., 18, 245-266, 1995.

Moustafa, A. R., El-Badrawy, R., and Gibali, H.: Pervasive E-ENE oriented faults in northern Egypt and their effect on the development and inversion of prolific sedimentary basins, Proceedings of the 14th Petroleum Conference, EGPC, Cairo, Egypt, 12-15 October 1998, 1, 51-67, 1998.
Moustafa, A. R., Saoudi, A., Moubasher, A., Ibrahim, I. M., Molokhia, H., and Schwartz, B.: Structural setting and tectonic evolution of the Bahariya Depression, Western Desert, Egypt, GeoArabia, 8, 91-124, 2003.

Needham, D. L., Pettingill, H. S., Christensen, C. J., Ffrench, J., and Karcz, Z.: The Tamar Giant Gas Field: Opening the Subsalt Miocene Gas Play in the Levant Basin, in: Giant Fields of the Decade 2000-2010, edited by: Merrill, R. K. and Sternbach, C. A., AAPG Memoir., 113, 221-256, https://doi.org/10.1306/13572009m1133688, 2017.

Neumaier, M., Back, S., Littke, R., Kukla, P. A., Schnabel, M., and Reichert, C.: Late Cretaceous to Cenozoic geodynamic evolution of the Atlantic margin offshore Essaouira (Morocco), Basin Res., 27, 1-19, 2016.

Neumaier, M., Ariyanto, P., Fraser, A. J., Aribi, N., Smith, S., and Nollet, S.: The exceptional 4D oil charge history of the Wytch Farm Field (Wessex Basin, UK), 79th EAGE Conference and Exhibition, Paris, June 12-15 2017, 1, 1-5, 2017.

Omodeo-Salé, S., Ondrak, R., Arribas, J., Mas, R., Guimerà, J., and Martínez, L.: Petroleum systems modelling in a fold-and-thrust belt setting-the inverted Cameros Basin, North-Central Spain, J. Petrol. Geol., 42, 145-171, 2019.

Panien, M., Schreurs, G., and Pfiffner, A.: Sandbox experiments on basin inversion: testing the influence of basin orientation and basin fill, J Struct. Geol., 27, 433-445, 2005.

Panien, M., Buiter, S., Schreurs, G., and Pfiffner, O.-A.: Inversion of a symmetric basin: insights from a comparison between analogue and numerical experiments, in: Analogue and Numerical Modelling of Crustal Scale Processes, edited by: Buiter, S. J. H. and Schreurs, G., Geological Society, London, UK, Geol. Soc. Spec. Publ., 253, 253-270, https://doi.org/10.1144/gsl.sp.2006.253.01.13, 2006.

Perez, N. D., Teixell, A., Gómez-Gras, D., and Stockli, D. F.: Reconstructing extensional basin architecture and provenance in the Marrakech High Atlas of Morocco: Implications for rift basins and inversion tectonics, Tectonics, 38, 1584-1608, 2019.

Phillips, T. B., Jackson, C. A.-L., and Norcliffe, J. R.: Pre-inversion normal fault geometry controls inversion style and magnitude, Farsund Basin, offshore southern Norway, Solid Earth, 11, 14891510, https://doi.org/10.5194/se-11-1489-2020, 2020.

Pogácsás, G., Mattick, R. E., Tari, G., and Várnai, P.: Structural control on hydrocarbon accumulation in the Pannonian Basin, Hungary, in: Basin Analysis for Oil and Gas Exploration: a Case History from Hungary, edited by: Teleki, P. and Kókay, J., Kluward, Amsterdam, the Netherlands, 221-235, https://doi.org/10.1007/978-94-011-0954-3_11, 1994.

Reilly, C., Nicol, A., and Walsh, J.: Importance of pre-existing fault size for the evolution of an inverted fault system, in: The Geometry and Growth of Normal Faults, edited by: Childs, C., Holdsworth, R. E., Jackson, C. A.-L., Manzocchi, T., Walsh, J. J., and Yielding, G., Geological Society, London, UK, Geol. Soc. Spec. Publ., 439, 447-463, https://doi.org/10.1144/sp439.2, 2017.

Roberts, D. G., Basin inversion in and around the British Isles, in: Inversion Tectonics, edited by: Cooper, M. A. and Williams, G. D., Geological Society, London, UK, Geol. Soc. Spec. Publ., 44, 131-150, https://doi.org/10.1144/gsl.sp.1989.044.01.09, 1989. 
Roberts, G. and Peace, D.: Hydrocarbon plays and prospectivity of the Levantine Basin, offshore Lebanon and Syria from modern seismic data, GeoArabia, 12, 99-124, 2007.

Roma, M., Vidal-Royo, O., McClay, K., Ferrer, O., and Muñoz, J. A.: Tectonic inversion of salt-detached ramp-syncline basins as illustrated by analog modeling and kinematic restoration, Interpretation, 6, T127-T144, 2018.

Rumpler, J. and Horváth, F.: Some representative seismic reflection lines from the Pannonian basin and their structural interpretation, in: The Pannonian Basin - a Study in Basin Evolution, edited by: Royden, L. and Horváth, F., AAPG Memoir., 45, 153-169, 1988.

Rowan, M. G.: Passive-margin salt basins: Hyperextension, evaporite deposition, and salt tectonics, Basin Res., 26, 154-182, 2014.

Ruszkiczay-Rüdiger, Z.., Fodor, L., Bada, G., Leél-Össy, S., Horváth, E., and Dunai, T. J.: Quantification of Quaternary vertical movements in the central Pannonian Basin: A review of chronologic data along the Danube River, Hungary, Tectonophysics, 410, 157-172, 2005.

Ruszkiczay-Rüdiger, Z.., Balázs, A., Csillag, G., Drijkoningen, G., and Fodor, L.: Uplift of the Transdanubian Range, Pannonian Basin: How fast and why? Global Planet. Change, in press, https://doi.org/10.1016/j.gloplacha.2020.103263, 2020.

Sibson, R. H.: Selective fault reactivation during basin inversion: potential for fluid redistribution through fault-valve action, in: Basin Inversion, edited by: Buchanan, J. G. and Buchanan, P. G., Geological Society of London, UK, Geol. Soc. Spec. Publ., 88, 3-19, https://doi.org/10.1144/gsl.sp.1995.088.01.02, 1995.

Song, T. G.: Inversion styles in the Songliao Basin (northeast China) and estimation of the inversion degree, Tectonophysics, 283, 173-188, 1997.

Stille, H.: Grundfragen der vergleichenden Tektonik, Gebrüder Borntraeger, Berlin, Germany, 443 pp., 1924.

Tari, G.: Alpine Tectonics of the Pannonian Basin, unpublished $\mathrm{PhD}$. thesis, Rice University, Houston, Texas, USA, 501 pp., 1994.

Tari, G. and Bérczi, I.: Simon Papp, a prominent Hungarian petroleum geologist: how to run exploration projects from a prison cell, in: History of the European Oil and Gas Industry, edited by: Craig, J., Gerali, F., Macaulay, F., and Sorkhabi, R., Geological Society, London, UK, Geol. Soc. Spec. Publ., 465, 409-422, https://doi.org/10.1144/sp465.19, 2018.

Tari, G. and Jabour, H.: Structural analogy between the inverted structures of the Moroccan Atlas system and the Syrian Arc structures of the eastern Mediterranean, AAPG Search and Discovery Article 30189, 2011.

Tari, G. and Jabour, H.: Salt tectonics along the Atlantic margin of Morocco, in Conjugate Divergent Margins, edited by: Mohriak, W. U., Danforth, A., Post, P. J., Brown, D. E., Tari, G. C., Nemcok, M., and Sinha, S. T., Geological Society, London, UK, Geol. Soc. Spec. Publ., 369, 337-353, https://doi.org/10.1144/sp369.23, 2013.

Tari, G. and Horváth, F.: Alpine evolution and hydrocarbon geology of the Pannonian Basin: an overview, in: The Carpathians and their foreland: geology and hydrocarbon resources, edited by Golonka, J. and Picha, F., AAPG Memoir, 84, 605-618, 2006.

Tari, G., Brown, D., Jabour, H., Hafid, M., Louden, K., and Zizi, M.: The conjugate margins of Morocco and Nova Scotia, in: Regional Geology and Tectonics: Phanerozoic Passive Margins, Cratonic Basins and Global Tectonic Maps, edited by: Roberts,
D. G. and Bally, A. W., Elsevier, Amsterdam, the Netherlands, 285-323, https://doi.org/10.1016/b978-0-444-56357-6.00007-x, 2012.

Tari, G., Novotny, B., Jabour, H., and Hafid, M.: Salt Tectonics Along the Atlantic Margin of NW Africa (Morocco and Mauritania), in: Permo-Triassic Salt Provinces of Europe, North Africa and the Atlantic Margins, edited by: Soto, J. I., Flinch, J., and Tari, G., Elsevier, Amsterdam, the Netherlands, 331-351, https://doi.org/10.1016/b978-0-12-809417-4.00016-1 2017a.

Tari, G., Flinch, J. F., and Soto, J. I.: Petroleum Systems and Play Types Associated With Permo-Triassic Salt in Europe, North Africa and the Atlantic Region, in: Permo-Triassic Salt Provinces of Europe, North Africa and the Atlantic Margins, edited by: Soto, J. I., Flinch, J., and Tari, G., Elsevier, Amsterdam, the Netherlands, 129-156, https://doi.org/10.1016/b978-012-809417-4.00007-0, 2017b.

Teixell, A., Arboleya, M., Julivert, M., and Charroud, M.: Tectonic shortening and topography in the central High Atlas (Morocco), Tectonics, 22, 1051, https://doi.org/10.1029/2002tc001460, 2003.

Tomljenović, B. and Csontos, L.: Neogene-Quaternary structures in the border zone between Alps, Dinarides and Pannonian Basin (Hrvatsko zagorje and Karlovac basins, Croatia), Int. J. Earth. Sci., 90, 560-578, 2001.

Tóth, T. and Tari, G.: Structural inversions in Western Hungary and Eastern Slovenia: their impact on hydrocarbon trapping and reservoir quality, AAPG Search and Discovery Article 30387, 2014.

Turner, J. P. and Williams, C. A.: Sedimentary basin inversion and intra-plate shortening, Earth-Sci. Rev., 65, 277-304, 2004.

Underhill, J. R. and Stoneley, R.: Introduction to the development, evolution and petroleum geology of the Wessex Basin, in: The Development, Evolution and Petroleum Geology of the Wessex Basin, edited by: Underhill, J. R., Geological Society London, UK, Geol. Soc. Spec. Publ., 133, 1-18, https://doi.org/10.1144/gsl.sp.1998.133.01.01, 1998.

Verges, J., Moragas, M., Martín-Martín, J. D., Saura, E., Razin, P., Grelaud, C., Malaval, M., Joussiaume, R., Messager, G., Sharp, I., and Hunt, D. W.: Salt tectonics in the Atlas mountains of Morocco, in: Permo-triassic Salt Provinces of Europe, North Africa and the Atlantic Margins. Tectonics and hydrocarbon potential, edited by: Soto, J. I., Tari, G., and Flinch, J., Elsevier, Amsterdam, the Netherlands, 563-576, https://doi.org/10.1016/b978-012-809417-4.00027-6, 2017.

Vrabec, M. and Fodor, L.: Late Cenozoic tectonics of Slovenia: structural styles at the Northeastern corner of the Adriatic microplate, in: The Adria microplate: GPS geodesy, tectonics and hazards, edited by: Pinter, N., Grenerczy, G., Weber, J., Medak, D., and Stein, S., 151-168, Springer, Dordrecht, the Netherlands, https://doi.org/10.1007/1-4020-4235-3_10, 2006.

Walley, C.: Some outstanding issues in the geology of Lebanon and their importance in the tectonic evolution of the Levantine region, Tectonophysics, 298, 37-62, 1998.

Wood, B. G. M.: Rethinking post-Hercynian basin development: Eastern Mediterranean region, GeoArabia, 20, 175-224, 2015

Williams, G. D., Powell, C. M., and Cooper, M. A.: Geometry and kinematics of inversion tectonics, in: Inversion Tectonics, edited by: Cooper, M. A. and Williams, G. D., Geolog- 
ical Society, London, UK, Geol. Soc. Spec. Publ., 44, 3-15, https://doi.org/10.1144/gsl.sp.1989.044.01.02 1989.

Withjack, M. and Callaway, S.: Active normal faulting beneath a salt layer: an experimental study of deformation patterns in the cover sequence, AAPG Bull., 84, 627-651, 2000.

Withjack, M. O., Olson, J., and Peterson, E.: Experimental models of extensional forced folds, AAPG Bull., 74, 1038-1054, 1990.

Yamada, Y. and McClay, K. R.: 3-D analog modeling of inversion thrust structures, in: Thrust Tectonics and Hydrocarbon Systems, edited by: McClay, K. R., AAPG Memoir., 82, 276-301, https://doi.org/10.1306/m82813c16, 2004.

Yang, F. L., Xu, X., Zhao, W. F., and Sun, Z.: Petroleum accumulations and inversion structures in the Xihu depression, East China Sea Basin, Journal of Petroleum Geology, 34, 429-440, 2011.

Yousef, M.,+ Moustafa, A. R., and Shann, M.: Structural setting and tectonic evolution of offshore north Sinai, Egypt, in: Evolution of the Levant Margin and Western Arabia Platform since the Mesozoic, edited by: Homberg, C. and Bachmann, M., Geological Society, London, UK, Geol. Soc. Spec. Publ., 341, https://doi.org/10.1144/sp341.4, 65-84, 2010.
Yousef, M., Yousef, M., and Sehim, A.: Structural style and evolution of inversion structures of Horus field, Alamein Basin, northern Western Desert of Egypt, Mar. Petrol. Geol., 110, 55-72, 2019.

Ziegler, P. A.: Late Cretaceous and Cenozoic intraplate compressional deformations in the Alpine foreland, Tectonophysics, 137, 389-420, 1987.

Ziegler, P. A.: Geodynamic model for Alpine intraplate compressional deformation in Western and Central Europe, in: Inversion Tectonics, edited by: Cooper, M. A. and Williams, G. D., Geological Society, London, UK, 63-85, https://doi.org/10.1144/gsl.sp.1989.044.01.05, 1989.

Ziegler, P. A., Cloetingh, S., and van Wees, J. D.: Dynamics of intraplate compressional deformation: the Alpine foreland and other examples, Tectonophysics, 252, 7-59, 1995. 